\title{
The Mental Alertness of School Principals in Kuwait and their Relation to Conflict Management Strategies
}

\author{
. Khalid Ahmad Al-Sarairah \\ Deanship of Scientific Research \\ Mutah University \\ dr.khaledsarairah@gmail.com
}

\author{
Hamad Mubarak Aqeel \\ Deanship of Scientific Research \\ Mutah University \\ mutahkh@gmail.com
}

Received:24/12/2020

Accepted:28/1/2021

\begin{abstract}
:
The study aims to identify the degree of mental alertness among the principals in Kuwait and its relation to conflict management strategies from the point of view of the teachers. The study consisted of (423) male and female teachers. They were selected in the simple random sampling method. The descriptive method was used. The researchers used a questionnaire consisting of (34) items for the areas of mental alertness (discrimination, attention, observation, awareness, and thinking) and (25) items for the areas of conflict management strategies (satisfaction, settlement, integration, avoidance, and domination). The availability of mental alertness among school principals in the State of Kuwait from the teachers' point of view came to a high degree, and that the arithmetic average of the level of school principals' practice in the State of Kuwait in conflict management strategies from the teachers' point of view was (high), and the presence of a positive statistically significant correlation between the estimates of the sample members on the degree of availability of mental alertness among school principals in the State of Kuwait and the level of their practice of conflict management strategies.
\end{abstract}

Keywords: mental alertness, organizational conflict strategies, school principals, teachers. 


\section{اليقظة الذهنية لاى مديري المدارس في دولة الكويت وعلاقتها باستراتيجيات إدارة الصراع}

$$
\text { عمد مبارك البحتث العلميل }
$$

mutahkh@gmail.com

\author{
خالد احمد الصرايرة

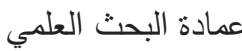

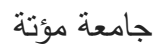

dr.khaledsarairah@gmail.com

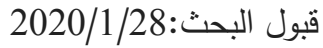

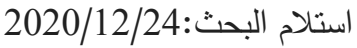

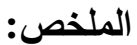

هدفت الدراسة إلى تعرّف درجة توافر اليقظة الذهنية لاى مديري الددارس في دولة الكويت وعلاقتها باستراتيجيات إدارة الصراع من وجهة نظر

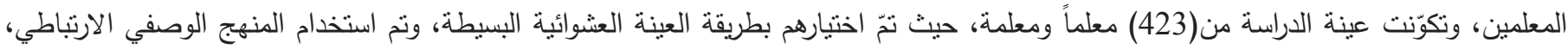
واستخدم الباحثان استبانة تكونت من (34) فقرة للجالات اليقظة الذهنية (التمييز، والانتباه، والملاحظة، والوعي، والتفكير) و و(25) فقرة لهجالات استراتيجيات إدارة الصراع (الإرضاء، والتسوية، والتكامل، والتجنب، والهيمنة) وأظهرت نتائج الدراسة أنّ المتوسط الحسابي لدرجة توافر اليقظة الذهنية لاى مديري المدارس في دولة الكويت من وجهة نظر المعلمين جاء بدرجة مرتفعة، وأنّ المتوسط الحسابي لمستوى ممارسة دديري الددارس في دولة

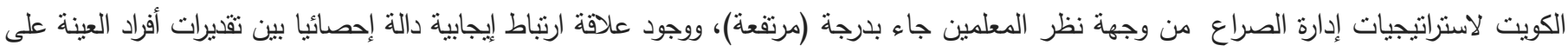
درجة نوافر اليقظة الذهنية لدى مديري الددارس في دولة الكويت ومستوى ممارستهم لاستراتيجيات إدارة الصراع. الكلمات المفتاحيّة: اليقظة الذهنية، استراتيجيات إدارة الصراع، مديرو المدارس، المعلمون، الكويت.

\section{المقدمة:}

اليقظة الذهنية بالمرونة وبالمقدرة على التعامل مع كل ما هو جديد

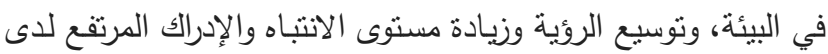

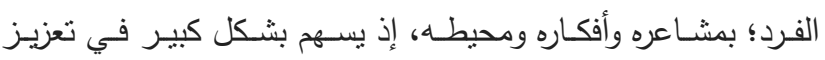

الصحة النفسية وتحسينها ليعيش الفرد حاضره بصورة مثالية(11).

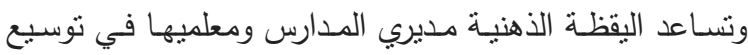
الرؤية، وزيادة الفرص لتعلُّم الجديد، وانتسامهم بالمرونة في تقبل الجديد لفيد

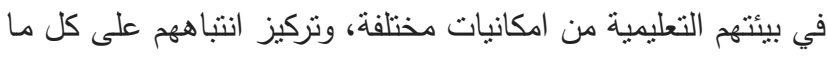

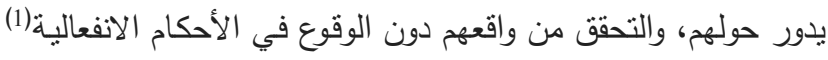

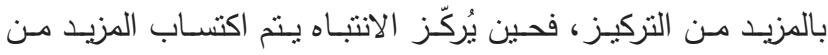

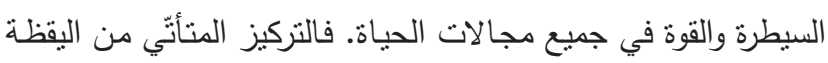

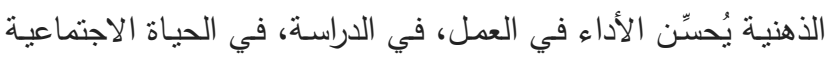

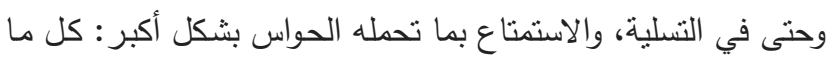

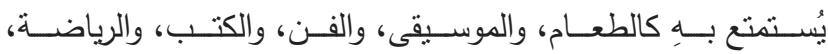
والرقص... يتحسن كثيراً حين يمنلك الإنسان المقدرة على الاسترخاء

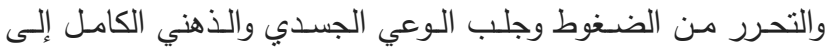

تُعدّ اليقظةُ الذهنية من المفاهيم النفسية السلوكية الحديثة نوعا

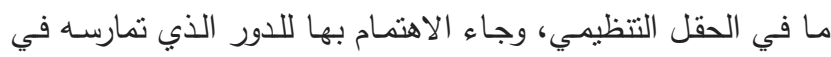

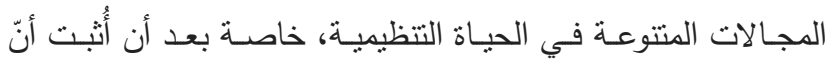
السلوك اليقظ يدفع الثخص إلى الاستجابة للبيئة، وبالتالي المعالجة المعرفية المرنة لأبعادها، فاليقظة الذهنية هي مؤشر للتفحص الاقيق لإنيق

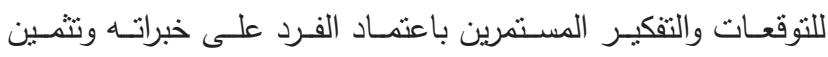

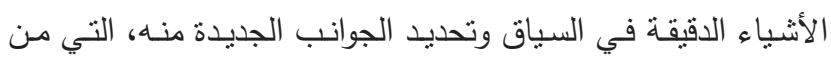

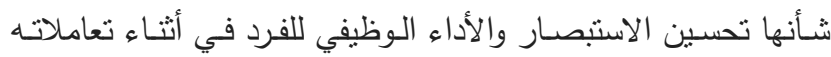

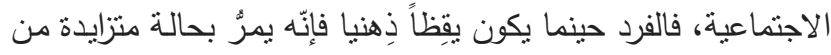

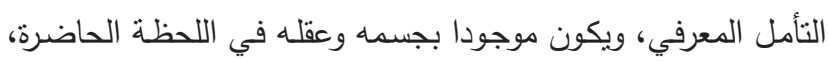

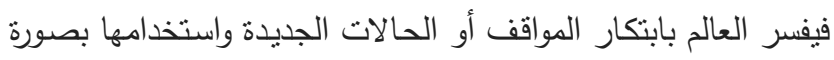
متواصلة دون انقطاع لفهم الظاهرة المفسرة.

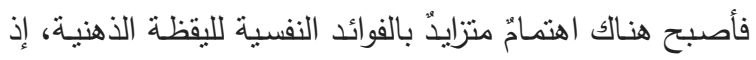

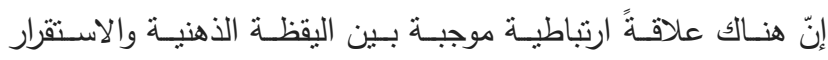

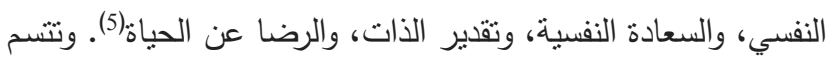


زيـادة فعاليـة المؤسسـة وجعلهـا تعدل على اجنيـاز مرحلـة القصور الذاتي وتحقيق أهدافها المرسومة بكفاءة. أنّ الصراع غالباً مـا يكون مُتنفّسـا طبيعيا للتوترات الحبيسـة الناتجة عن تعارض الأهداف والدوافع والحاجات. 6. أنه يحث الأفراد ويُزودهم بطاقات جديدة تساعد على إيجاد

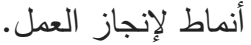
7. أنـه يسـاعد على إثـبـاع الحاجـات النفسية لـبعض الأفـراد وخاصة ذوي الميول العدوانية. 8. يعمل على تماسلك الجماعة عندما تكون على اختلاف مـع

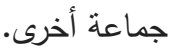
9. يقود في بعض الأحيـان إلى تحسـين جـودة القرارات التي تتخــذها الإدارة فــي ظـلـ ظــروف المنافسـة حيــث يميــل المـديرون إلـى اتخـاذ قـرارات أفضــل نوعيــة بالمقارنــة مـعـع القرارات المتخذة في الظروف العادية.

الدراسات السابقة ذات الصلة ناليـاً عـرضُ لبعض الدراسـات السـابقة التـي تتاولت متغيـرات

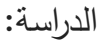

- الاراسات المتعلقة باليقظة الذهنية: أجرى غيج(7) دراسـة هدفت إلى وضـع عدد من المقاييس التي يمكن اعتمادها في قياس اليقظة الذهنيـة لدى العاملين في المدارس المتوسطة في ولايـة اوهايو الأمريكية ، وقد تكونت عيّنة الدراسـة من (75) مدرسـة متوسـطة، واسـتخدمت الاسـتبانة وسـيلة لجمـع بيانـات الدراسة. وأظهرت النتائج وجود علاقة ايجابية دالة إحصائيا بين درجة تمكين الهيكل التظظيمي للمدرسة، ودرجة اليقظة الذهنية لدى العاملين في المـارس المتوسطة، لهيكل التظظيمي للمدرسـة. ودرجـة اليقظة الذهنية لاى العاملين في المدارس المتوسطة، فضلا عن وجود علاقة ايجابية دالة إحصائياً بين الفاعلية التتظيمية واليقظة الذهنية في هذه المدارس.

وهـدفت دراسـة رودريكس (15) إلى تعـرف العلاقـة بـين اليقظـة

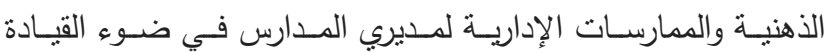
التعليميـة اليقِظـة ذهنبـاً في ولايـة واشـنطن الأميركيـة، وتمّ اسـتخدام المنهج الوصفي التحليلي، وطبقت هذه الدراسـة على عينـة تكونت من (505) مـدراء في ولايـة واشـنطن الأميركيـة، وتم اسـتخدم الاسـتبانة وسيلة لجمع البيانات، وأظهرت النتائج وجود علاقة ارتباطية إيجابية دالة إحصائياً بين اليقظة الذهنية التي يتمتع بها المديرون وممارساتهم الإداريـة المسـتـدة إلـى القيـادة التعليميـة التـي يتبنونهـا في قيـادتهم

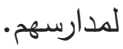

وهدفت دراسـة حمد (1) إلىى تعرف درجـة توافر اليقظة الذهنيـة لدى مديري المدارس الحكومية في محافظة عَمّان وعلاقتها بمستوى
الحواس، والمزيد من اليقظة الذهنية تجاه المشاعر ، حين يكون الأفراد متيقظين تجاه كينونتهم الداخلية، سيكون لديهم مقدرة متصـاعدة على ملاحظــة حالـة تغيـرات مشــاعرهم الحقيقيـة وخاصــة تلــك السـلبية، والاتصـال بشكل أعمق مـع الآخرين، حين ينّم تحقيق مستوى معين من السـام الداخلي، وتتسحب الأعباء إلى الخلفية الصـامتة، سيكون بالإمكـان الاتصــال بشـكل أعمـق مــع الآخـرين وتعزيـز عرفـانهم بالجميل، والتعاطف، وتقتح الذات تجاه البعد الروحي: الثعور المنزايد بالحريـة الداخلية، السـلام والوعي يربطنا أكثر بالثـعور بغايـة تتجاوز

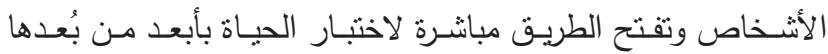
المادي.

ويُعدُّ الصـراعُ بين المعلمـين ظـاهرة شـائقة لا يمكن تجنّبهـا أو القضاء عليها نظراً للاختلافات الشخصية والفكرية والثقافية والتربوية والاجتماعيـة والاقتصـادية بين المعلمين، وتباين السمات الثخصية، الأمر الذي يؤدي بدوره إلى التباين بين المعلمين فيما يتعلق بالاتفاق على الأهداف، والإجراءات، والوسائل لبلوغ أهداف المدرسة، وظهور المشكلات السلبية ببين المعلمين في صسورة عدم الثقة والخوف ممـا يؤدي إلى نشوء الصراع(8). وأمّا مفهوم استراتيجيات إدارة الصـراع التنظيمي فيرى(14) بأنـه يمثنل مجموعـة السـلوكيات التـي يتبعهـا الإداريـون في التعامـل مـع المواقف الحادة في المؤسسة سواء أكانت بين المعلمين أنفسهم أم بين

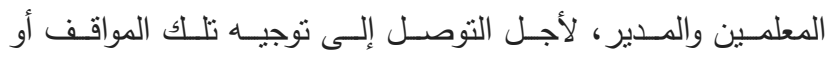
الصراعات نحو مسارات تخدم المصلحة العامة وتحقيق أهداف النظام

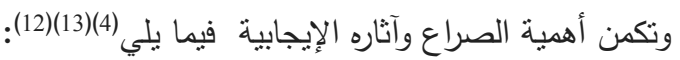

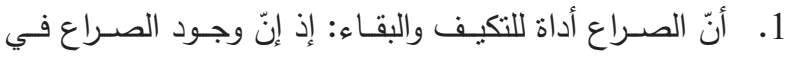
المؤسســة يُحنّم على الإدارة مواجهته ومعالجتـه ممـا يـفعها

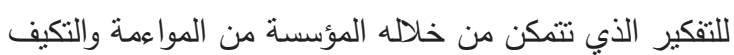

$$
\text { بهدف استمرارها ونموها. }
$$

2. الصراع أداة لنطوير وتحفيز قدرات المدير المعاصر : حيث

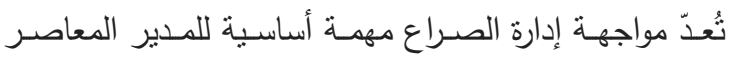
الذي يُنتظر منه مواجهتُه وإدارته لا كيفيةُ كبح جماحه بوصفه شرّا. 3. الصـراع أداة للإببداع: بينت الدراسـات أنّ هناك علاقـة بـين الصراع والأداء والإبداع ، فعندما لا يكون هناك صراع على

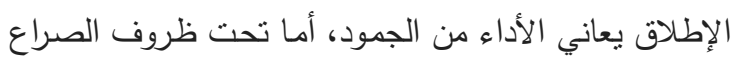
المحدودة والمسيطر عليها فيمكن أنْ ينشأ لدى الأفراد الدافعية الإسية للمبـادرة والإبـداع ، وفي نفس الوقت فـإنّ المسـتوى المرتفـع للصراع والذي يوصف بالعنف وعدم التعاون سيؤثر سلبا في

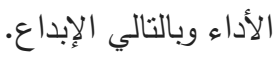
4. الصراع أداة لتشغيل حركة المؤسسة: يزداد الاهنمام بالصراع الإبـاع ليس لكونـه سببا في الإرباك والفوضسى بـل لكونـه سببا في 
المنظمات، ومهارات إدارة الصراع بفعالية في الصين، استُخدم المنهج الوصفي المسـي، والوصـي الوثائقي، ولتحقيق أهداف الدراسـة قـام الباحثـان بـإجراء مقـابلات مـع المـوظفين والمـديرين في المنظمـات الصينية وأسفرت الدراسة عن عدد من النتائج منها: أنّ التدربب على الصـراعات يسـاعد على فهم أسس وقواعد إدارة الصـراع، واكتسـاب مهارات إدارة الصراع بفعالية، وأنّ استراتيجية الأسلوب التعاوني كأحد الأسـاليب الرئيسـة لإدارة الصـراع في الصـين تتضـمن ابتكار الأفكار

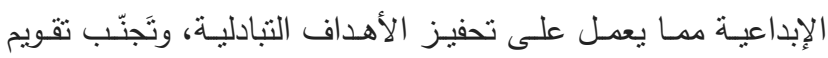
الأفكار المتعجل،والوصـول إلى اتفاق على عدة قضـايا لكي يثـعر الأفـراد بحمايـة حقـوقهم، وتقـويم المقترحـات طبقًا لمعـايير العدالـة والفاعلية.

وأجرى غنيم(8) دراسـة هدفت إلى التعرف على مدى ممارسـة المديرين لاستراتيجيات إدارة الصـراع بين المعلمين (التجنب، والقوة، والتوافق، والتسوية، والتكامل)، والكثف عن الفروق بين آراء المديرين والمعلمين حول مدى ممارسة المديرين لاستراتيجيات إدارة الصراع بين المعلمـين، وتـم اسـتخدام المـنهج الوصـفي التحليلي، وتكوّتـت عينـة الدراسة من (341) فردا، واستُخدم المنهج الوصفي المسحي، ولتحقيق أهداف الدراسـة أعد الباحث استبانة، وتوصلت الدراسـة إلى عدد من

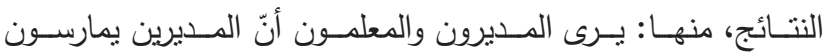
استراتيجية التوافق في إدارة الصراع بين المعلمين بدرجة عالية، بينما يمارسون استراتيجيتي التكامل والتسوية بدرجة منوسطة، واستراتيجية القوة بدرجـة ضـعيفة بينمـا يـرى المـديرون أنهـ يمارسـون اسـتراتيجية التجنب بدرجة ضعيفة، في حين يرى المعلمون أنّ المديرين يمارسونها بدرجة متوسطة، وتوجد فروق ذات دلالة إحصائية بين آراء المديرين والمعلمين حول مدى ممارسة المديرين لاستراتيجيتي التوافق والتكامل

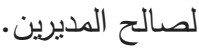
وهدفت دراسة عوان وسعيد(6) إلى تعرف واقع الصراع وأسبابه، والحلول الممكنة لتحسين بيئة العمل في المؤسسـة. واعتمدت الدراسـة على المنهج الوصفي التحليلي، وتمثلت عينـة الدراسـة مـن (201) موظف من العاملين في القطاع التعليمي في باكستان، وتم استخدام الاستبانة أداة للاراسة، وقد توصلت الدراسة إلى عدد من النتائج، كان من أهمها: عدم وجـود أثر لآراء المبحوثين حول استراتيجيات إدارة الصراع يُعزى لمتغير التعليم، وعدم وجود فروق ذات دلالة إحصائية بين آراء المبحوثين حول أسباب الصراع يُعزى لمتغير الجنس، ووجود أثز ذي دلالة إحصائية للصراع على الأداء التنظيمي. وقام الجنابي (3) بدراسة هدفت إلى تعرّف درجة ممارسة مديري المــدارس المتوســة بمحافظــة بغــداد لاسـتراتيجيات إدارة الصــراع التتظيمي. ولتحقيق أغراض الدراسة استخدم الباحث المنهج الوصفي التحليلي وتكونت عينـة الدراسـة مسن (215) مـديراً ومـديرة للمـدارس المتوسطة يمثلون كافة مجتمـع الدراسـة، وقد استخدم الباحث استبانة
التقة التظيمية للمعلمين من وجهة نظرهم، وتكونت العينة من (291)

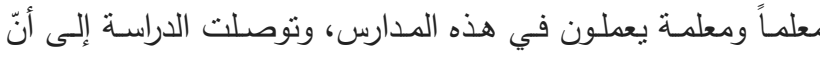
درجة نوافر اليقظة الذهنية لدى مديري المدارس الحكومية في محافظة

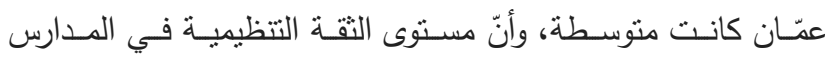
الحكوميـة في محافظـة عمّان كـان مرتفعـا، ووجـود علاقـة ارتباطيـة موجبة بين درجة اليقظة الذهنية ومستوى الثقة التظيمية. وهدفت دراسة الهاشم(2) إلى تعرُّف درجة توافر اليقظة الذهنية لاى مديري المدارس الثانوبـة الحكومية في محافظة عمّان، وعلاقتها بدرجة ممارسة سلوك المواطنة التتظيمية للمعلمين من وجهة نظرهم. ونم استخدام المنهج الوصفي التحليلي، وقد تكونت عينة الدراسـة من (313) معلماً ومعلمة نم اختيارهم بالطريقة الطبقية العشوائية النسبية، ولجمع البيانات استُخدمت أداتان: الأولى لقياس العلاقة بين اليقظة الذهنية، والثانبة لقياس سلوك المواطنة التتظيمية. وكانت النتائج أنّ درجة توافر اليقظة الذهنية لدى مديري المدارس الثانوية الحكومية في محافظة عمّان كانت منوسطة، كما أنّ درجة ممارسـة سلوك المواطنة التنظيمية للمعلمين متوسطة، ووجود علاقة ارتباطية إيجابية بين درجة تـوافر اليقظـة الذهنيـة لـدى مـديري المـدارس الثانويـة الحكوميـة في مي محافظة عمّان ودرجة ممارسة سلوك المواطنة التظظيمية للمعلمين من وجهة نظرهم.

- الدراسات المتعلقة باستراتيجيات إدارة الصراع: هدفت دراسـة هنكين وآخرين (9) إلى تعرُّف الاستراتيجيات التي بسـتخدمها المـديرون في إدارة الصـراع، والتعـرف إلىى العلاقـة بـين استراتيجيات إدارة الصراع التي بستخدمها المديرون وكلٍ من الجنس إنس والعهـر ، والمسـتوى التعليمسي، والخبـرة العمليـة، والمرحلـة التعليميـة، والرضـا عن الإدارة المحلية في مدارس المدن المدارة محليا بمنطقة تعليمية جنوب شرق الولايات المتحدة الأمريكية. تكونت عينة الدراسـة مـن (300) مـدير ومـديرة اسـتجاب مـنهم (103) مـديرين ومـديرات. اسـتُخدم المنهج الوصفي المسـي، ولتحقيـق أهداف الدراسـة أُعدّت استبانة تكونت من (29) فقرة، توصلت الدراسة إلى عدد من النتائج منها: أن المديرين يُفضلون استخدام استراتيجية الحل التكاملي لإدارة الصـراع في حل المشكلات، ثم تأتي في المرتبـة الثانيـة استراتيجية القوة ثم الانسـاب، ولا توجد علاقـة ارتباطية بين نسوع الاستراتيجية التي يستخدمها المديرون في إدارة الصراع وكلٍٍ من الجنس، والعمر، ، والمستوى التعليمي، والخبرة العملية، والمرحلة التعليمية، كما أظهرت الدراسـة أنّ المـديرين الذين يشـعرون برضـا عـالٍ عن أسـلوب الإدارة المحلية يمارسون استراتيجية الحل التكاملي في حل الصراعات. وأجرى الباحثان تجوسفولد ودينج(16) دراسة هدفت إلى التعرف على أهميـة التدريب على إدارة الصـراع، واستراتيجية - الأسـلوب -

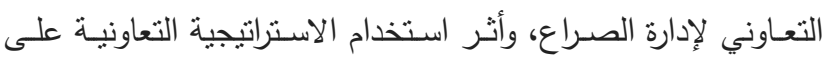


السـؤال الأول: مـا درجـة توافر اليقظـة الذهنيـة لدى مـديري

المدارس في دولة الكويت من وجهة نظر المعلمين؟ السؤال الثاني: ما مستوى ممارسة مديري المدارس في دولة

الكويت لاستراتيجيات إدارة الصراع من وجهة نظر المعلمين؟ السؤال الثالث: هل هناك علاقة ارتباطية ذات دلالة إحصائية عند مسنوى (10.05) بين درجـة توافر اليقظة الذهنية لدى مديري المـدارس في دولـة الكويـت ومسـتوى ممارسـتهم لاسـتراتيجيات إدارة الصراع؟

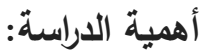

تتمنل أهمية هذه الدراسة بما يلي:

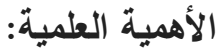

- تُعدّ هذه الدراسة الأولى من نوعها -في حدود علم الباحثَين - التي تتاولت اليقظة الذهنية وعلاقتها باستراتيجيات إدارة الصـراع للى

$$
\text { مديري المدارس. }
$$

- - توفير إطار نظري عن اليقظة الذهنية واستراتيجيات إدارة الصراع

باعتبارهما من المتغيرات الحديثة في الإدارة التربوية. - يؤمل أنْ تفيد هذه الدراسة العديد من الباحثين في وضع البرامج الإرشادية المختلفة لتتمية اليقظة الذهنية وتتمية استراتيجيات إدارة

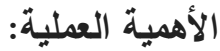

- قد تُسهم هذه الدراسـة في تزويد مديري ومديرات المـارس بدولة الكويت، بالتغذية الراجعة لعملية التقويم الذاتي لسلوكهم الإداري في اليقظة الذهنية وإدارة استراتيجيات الصراع. - - يتوقع أن تقيد هذه الدراسة أصحاب القرار في وزارة التربية في دولة الكويت. - - التعرف إلى اليقظة الذهنية واستراتيجيات إدارة الصراع السائدة التي يتبعها مديرو ومديرات المدارس في دولة الكويت، والذي سـيوفر مجـالاً لتعزيـز الأنـواع الايجابيـة منهـا، والتقليـل مـن الاسـتراتيجيات غيـر الملائيسة وضـرورة اسـتخدام الأسـاليب

العلمية بدلاً من اعتماد الأساليب التقليدية بالتجربة والخطأ.

\section{مصطلحات الاراسة:}

استخدم الباحثنان عدد مـن المصطلحات التي مـن الضـروري
موزعة على مجالات الدراسة (التتافس، والتجنب، والتعاون، والتسوية، والتتازل)، وأظهرت نتائج الدراسـة أنّ الاستراتيجية الأكثر شيوعاً بين أوساط مديري المدارس المتوسطة كانت استراتيجية التعاون، وأنّ درجة ممارسـة المديرين للاسـتراتيجيات المختلفـة تتازليـاً كالتالي :(التعـاون،

والتسوية، والتنازل، والتتافس، والتجنب).

\section{ما يميز الدراسة الحالية عن الدراسات السابقة}

يتضح من خـلال عرض الدراسات السابقة التي تتاولت اليقظة الذهنية أنّ هذه الدراسات قد تعددت واختلفت باختلاف الأهداف التي سعت إلى تحقيقها، واختلاف مجتمعات الدراسة التي طبقت عليها مثل غيج(7) ودراسة رودربكس(15) ودراسة حمد(1) ودراسة الهاشم(2).

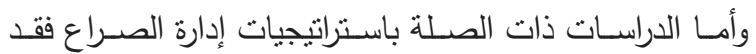
هـدفت تجوسـفولد وديـنج(16) إلـى تعـرف أهميـة التدريب على إدارة الصراع، واستراتيجية - الأسلوب - التعاوني لإدارة الصراع، وهدفت دراسـة هنكين وآخـرين (8 إلىى تعـرف الاسـتراتيجيات التـي يسـتخدمها المديرون في إدارة الصـراع، وهدفت دراسـة غنيم(8) إلى التعرف على مـدى ممارسـة المـديرين لاسـتراتيجيات إدارة الصـراع بـين المعلمـين، وهدفت دراسـة الجنابي (3) للتعرف إلى درجة ممارسة مديري المدارس لاسترس المتوسطة بمحافظة بغداد لاستراتيجيات إدارة الصراع التنظيمي.

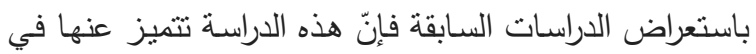
كونها تبحث في اليقظة الذهنية لدى مديري المدارس في دولة الكويت وعلاقتها باستراتيجيات إدارة الصراع من وجهة نظر المعلمين، وندرة الدراسات التي تتعلق بالموضوع.

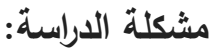

يسـاعد انتباه الأفراد على انتقاء المثيرات المناسبة من البيئة الخارجية، وغالبا ما يُوجَّهَ انتباه الفرد بشكل مباشر للمثيرات الجديدة وغير العاديـة والتي هي من خصائص الأفراد الذين يمتازون بيقظة ذهنيـة، ويكونون واعين بشكل كامل بالبيئة التي يعملون فيها، وأنهم يعلمون ما يدور حولهم لحظة بلحظة وبدون شرود ذهني. ولأنّ اليقظة الذهنية تُعزز الرفاه، وتخفف من الصراع، وتعالج الضـغوط النفسية، وتعدـل على خفض التـوتر والقلت واضـطرابات المزاج لدى مديري المدارس في الكويت مما يجعلهم قادرين على حلّ الخلافات والتتاقضات التي تحصل بين المعلمين، وتوفير مناخ دراسي دائم ومستقر يمـلأ الوفـاق والوئـام بين المعلمين، فقد أوصـت دراسـة الهاشم(2) بضرورة الكثف عن اليقظة الذهنية لاى مديري المدارس في الكويت والعمل على تعزيزها وتتميتها، والعمل على توجيه المرشدين التربويين إلى ضرورة إعداد البرامج اللازمة لتتميتها.

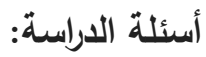

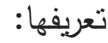

تتبثت مشكلة الدراسة من خلال الإجابة عن الأسئلة الآتية: 


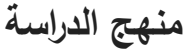

قام الباحثان باعنماد المنهج الوصفي الارتباطي نظراً لملاءمته

لطبيعة وأهداف الدراسة الحالية.

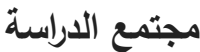

تكون مجتمع الدراسة من جميع المعلمين والمعلمات الملتحقين بعطهم خلال العام (2019/2018) في دولة الكويت، والبالغ عددهم (18457) معلما ومعلمة حسب إحصائية وزارة التربية لسنة (2019).

عينة الدراسة

تكونـت عينـة الدراسـة مـن (423) معلمـاً ومعلمـة تـم اختيـارهم

بطريقة العينة العشوائية البسيطة.

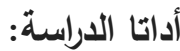

لتحقيق أهداف الدراسة تمّ تطوير أداتين: الأولى لقياس درجة

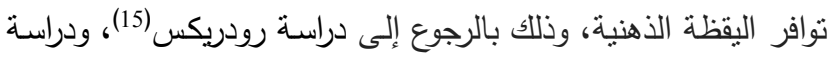

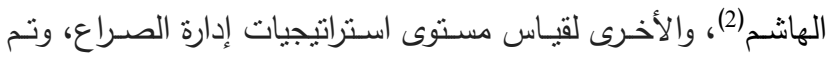

الاستفادة من دراسة غنيم (8)، ودراسة الجنابي (3).

\section{صدق محتوى أداتي الاراسة:}

تم التأكد من صدق محتوى أداتي الدراسة بعرضهما على

(10) مُحكّمين من المختصين بالعلوم التربوية في الجامعات الأردنية

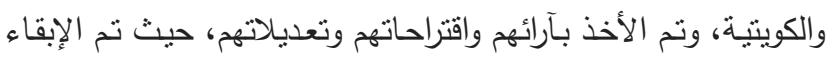
على الفقرات التي اتفق عليها ما يزيد عن (80\%) من المُحكمّين وتم

تعديل صباغة بعض الفقرات، ولم بتم حذف أي فقرة من فقراتها.

$$
\text { ثبات أداتي الدراسة: }
$$

تم تقييم درجة ثبات الأداة بطريقة الاتساق الداخلي (كرونباخ

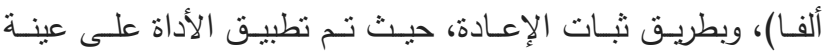

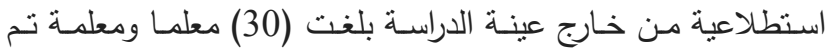
اختيـارهم بطريقة عشـوائية، وتم استخراج معامل الثبات بالاتسـاق الداخلي والثبات بالإعـادة لمجـالات الأداة والدرجـة الكليـة وفيمـا يلي لئي

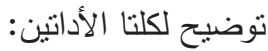

اليقظة الذهنية: نعرفها الهاشم(2) بأنها: " درجة وعي الفرد

بالخبرات الموجودة في اللحظة التي حدثت بها دون إصدار الأحكام، إذ ينظر إلى اليقظة الذهنية على أنها حالة بالإمكان القيام بتتميتها من خـلال ممارسـات وأنثطة مثثل التفكر والثأملس". وتُعرّف إجرائياً بأنها: ابتكار مديري مدارس دولة الكويت للأفكار الجديـة، والانفتاح على المعلومات الجديدة، وتكون في معرفة نقديرات عينة الدراسة من المعلمين لدرجة اليقظة الذهنية لاى مديري المدارس في دولة الكويت

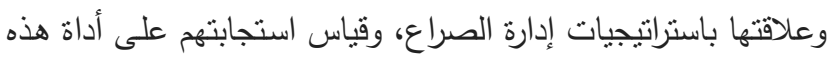

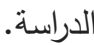

\section{اسـتراتيجية إدارة الصـــراع: ويعرفهـا مـرزوق(10) بأنهـا}

"الطريقة التي يستخدمها الديرون في حل الخلافات بين الأطراف المتصارعة التي قد تعزز من فرص الوصول إلى اتفاق، أو قد تكون إدارة هدامـة في حل الصـراع إذا أسيئ استخدامها". وتُعرّف إجرائياً

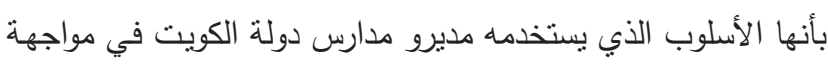

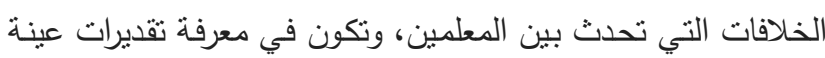
الدراسة من المعلمين لدرجة اليقظة الذهنية لدى مديري المدارس في لئي

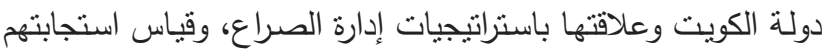

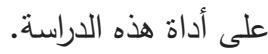

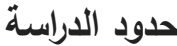

$$
\text { تمنتل حدود الدراسة فيما يلي: }
$$

- الحد الموضوعي: اقتصر موضوع الدراسة على اليقظة الذهنية لدى مديري المدارس في دولة الكويت وعلاقتها باستراتيجيات إدارة الصراع من وجهة نظر المعلمين. - الحـــ البشـري: طُبقت الدراسـة على عبنـة ممثلـة مـن مديري ومديرات المدارس في دولة الكويت. - الدد المكاني: طُبقت الدراسة على الددارس في دولة الكويت. - الحد الزماني: تم تتفيذ هذه الدراسة خلال الفصل الدراسي

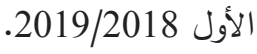

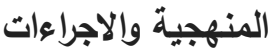

\begin{tabular}{|c|c|c|c|}
\hline الثبات بالإعادة & الثبات بالاتساق الداخلي & 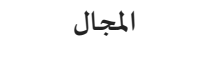 & المتغير \\
\hline 0.96 & 0.96 & الانتباه & \multirow{6}{*}{ ليقظة الذهنية } \\
\hline 0.92 & 0.89 & التمييز & \\
\hline 0.94 & 0.94 & الملاحظة & \\
\hline 0.92 & 0.93 & التفكير & \\
\hline 0.90 & 0.89 & الوعي & \\
\hline 0.98 & & الأداة ككل & \\
\hline 0.91 & 0.90 & استراتيجية التكامل & \\
\hline
\end{tabular}

جدول (1) معامل الثبات بالاتساق الداخلي والثبات بالإعادة لمجالات الأداة والدرجة الكلية 


\begin{tabular}{|c|c|c|c|}
\hline الثبات بالإعادة & الثبات بالاتسـاق الداخلي & 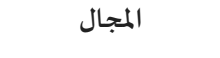 & المتغير \\
\hline 0.90 & 0.89 & استراتيجية التجنب & استراتيجيات إدارة الصراع \\
\hline 0.93 & 0.92 & استراتيجية الهيمنة & \\
\hline 0.90 & 0.92 & استراتيجية التسوبة & \\
\hline 0.92 & 0.96 & استراتيجية الإرضياء & \\
\hline 0.91 & & الأداة ككل & \\
\hline
\end{tabular}

جدول (2)

المتوسطات الحسابية والانحرافات المعيارية لدرجة توافر اليقظة الذهنية لدى

مديري المدارس في دولة الكويت من وجهة نظر المعلمين مرتبة تنازليًا

\begin{tabular}{|c|c|c|c|c|c|}
\hline الدرجة & الرتبة & المعياري & الحستابي & البعد & الرقم \\
\hline مرتفعة & 1 & 0.59 & 3.83 & التمييز & 2 \\
\hline مرتفعة & 2 & 0.67 & 3.81 & الانتباه & 1 \\
\hline مرتفعة & 3 & 0.87 & 3.78 & الملاحظة & 3 \\
\hline مرتفعة & 4 & 0.63 & 3.71 & الوعي & 5 \\
\hline مرتفعة & 5 & 0.63 & 3.69 & التفكير & 4 \\
\hline مرتفعة & & 0.61 & 3.76 & ككل اليقظة الذهنية & \\
\hline
\end{tabular}

يُبين الجدول (2) أنّ المتوسطات الحسابية لمجالات الدراسـة تراوحت ما بين (3.83-3.69) حيث جاء مجال التمييز في المرتبة

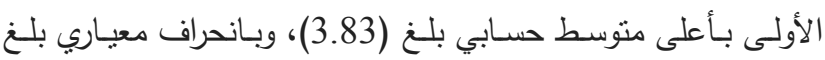
(0.59)، وبدرجـة مرتفعـة، تـلاه فـي المرتبـة الثنانيـة مجـال الانتبـاه بمتوسط حسابي بلغ (3.81)، وبانحراف معياري بلغ (0.67)، وبدرجة مرتفعة، تلاه في المرتبة الثالثة مجال الملاحظة مجال الانتباه بمنوسط حسابي بلغ (3.78)، وبانحراف معياري بلغ (0.87)، وبدرجة مرتفعة،

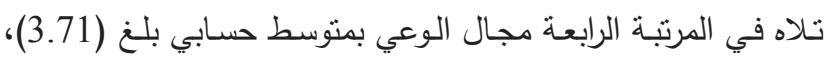

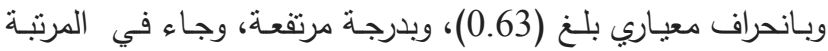

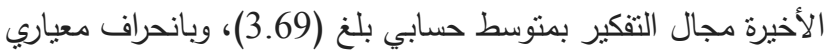

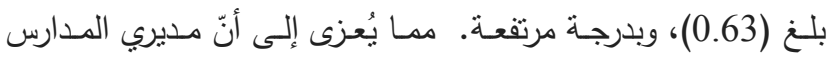

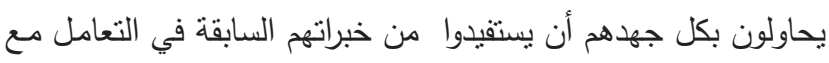
المواقف المستقلية أو الحالية التي تواجههم، ويشجعون الفعاليات في بلي المدرسة ويندمجون معها ويسهلونها ويقدمون على الدعم المطلوب، كما أنّ عندهم المقدرة على مواجهة تحديات العمل من خلال إنجاز

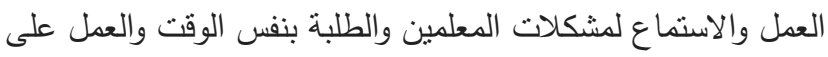

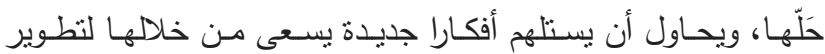
العمل، كما أنّ مديري المدرسة يتمتعون بحب الاستطلاع للتعرف إلى بلى كل ما هو جديد في مجال عملهم دما يؤدي إلى تطوير العمل وتتميته مما يؤدي به إلى التميز والإبداع ويكون من خلال مشاركتهم للمعلدين والاستفادة من آرائهم وخبراتهم، وتفعيل دورهم في الددرسة، وامتلاك مديري المدارس المقدرة على تسيير شؤون العمل والعمل على طرح

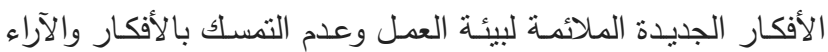

يبين الجدول (1) قيم معاملات ألفا كرونباخ لمجالات ومحاور

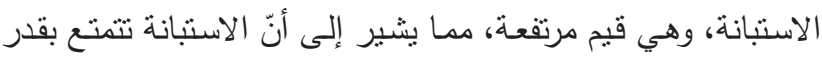

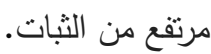

\section{تصحيح أداتي الدراسة}

تمّ الاستجابة على الأداتين بحسب تدريج ليكرت الخماسي لـاسي (موافق بشدة، موافق، محايد، غير موافق، غير موافق بشدة)، وتعطى الآنى

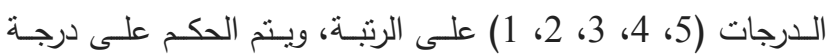
الموافقة بالاعتماد على المعيار التالي:

\begin{tabular}{|c|c|}
\hline المعالجات الإحصائية & المتئ| \\
\hline
\end{tabular}

للإجابة عن اسئلة الدراسة نم استخدام الإحصائيات التالية: لتحقيق أهداف الدراسـة تم استخدام برنامج الحُزم الإحصـائية للعلوم الاجتماعية (SPSS) لتحليل البيانات والحصول على النتائج

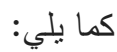
للإجابة عن السؤال الأول والثاني ثم استخدام:

• التكرارات والنسب المئوية لوصف خصائص عينة الدراسة.

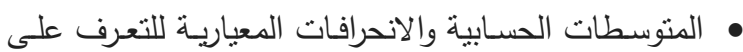
استجابات أفراد العينة على كل عبارة من عبارات الاستبانة.

$$
\text { • ولإجابة عن السؤال الثالث تم استخدام: }
$$

• معامل ارتباط بيرسون (Pearson Correlation) للتحقق من صدق الاتساق الداخلي للاستبانة.

\section{عرض نتائج الدّراسة ومناقتشتها والتّوصيات}

النتائج المتعقة بالسؤال الأول والذي ينصّ على: مـا درجة

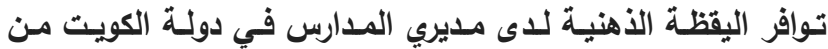

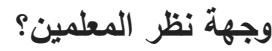
ولإجابـة عن هذا السؤال تم استخراج المتوسطات الحسـابية والانحرافات المعيارية لمعرفة درجة توافر اليقظة الذهنية لاى مديري المدارس في دولة الكويت من وجهة نظر المعلمين، والجدول (2)

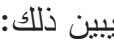


يبين الجدول (3) أنّ الفقرة (8) والتي نصّت على " أنّه يوجّهـ

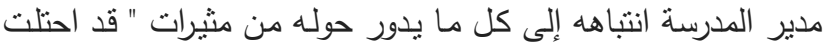

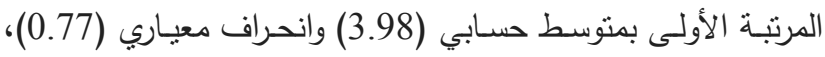
مدا يُعزى إلى أنّ أغلب مديري المدارس ومديراتها يمتلكون المقدرة على الانتباه والتركيز في الأعمال التي يمارسونها، وعندهم المقدرة على السيطرة والاندماج بأكثر من عمل، ومعرفة ما يجري حولهم من الاعن

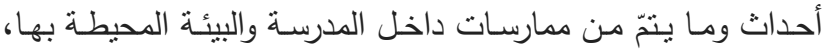
والمقدرة على التعامل معها، ويتم الحفاظ عليها وإدامتها في ضوء دماء الخبرة المباشرة المكتسبة منهم، مما يسمح بزيادة تمييز الأحداث التي

تحدث في وقتها.

بينما احتلت الفقرة (2) والتي نصّت على " لدى مدير المدرسة

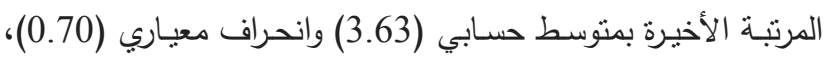
مما يُعزى إلى أنّ بعض مديري المدارس ومديراتها يحاولون التعامل مع المشكلات الني تواجهرم بشكل سريع وعدم الدخول في تفاصيلها من أجل العمل على إتمام العملية التعليمة.

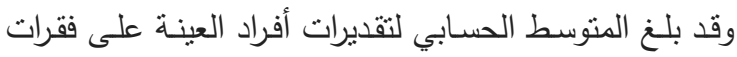
هذا الججال ككل (3.81) وانحراف معياري (0.67)، وهو يقابل تقدير

$$
\text { بدرجة مرتفعة. }
$$

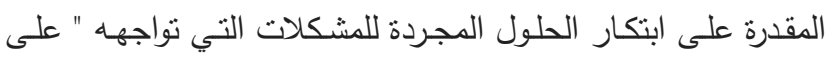

الخاطئـة أو غيـر المجديـة والبحـث عـن بـديل، واحتـرام المعلمـين

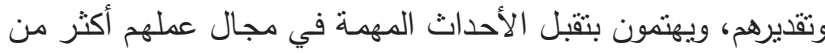
التحكم فيها، مما يزيد من كفاءة العمل وجودته والحصول على الجودة

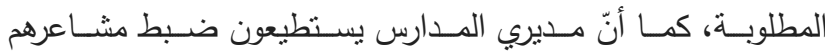
والتصرف بحكمة في المواقف التي تقتضي ذلك، وامتلاكهم الوعي الكامل عندما يستقبل وجهات نظر الآخرين، وامتلاك المقدرة على

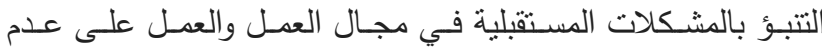
حدوثها، واتخـاذ الـلازم قبـل وقوعها، ويمتلكون المقدرة على تسيير

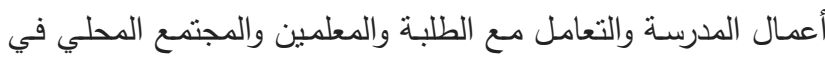

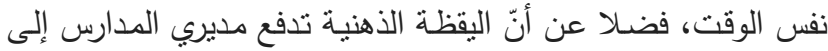
تعزيز تتمية وتطوير الذات، فضلا عن تحسين الثقة بالنفس، وتعزز الوصول إلى آفاق جديدة والانفصال عن الاستجابة التلقائية للأفكار

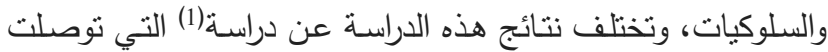
إلى أنّ درجة نوافر اليقظة الذهنية لدى مديري المدارس الحكومية في

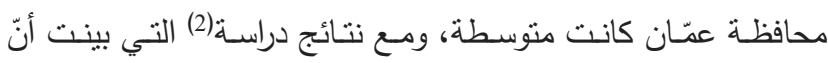
درجة نوافر اليقظة الذهنية لدى مديري المدارس الثانوية الحكومية في محافظة عمّان كانت منوسطة.

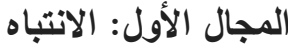
للإجابـة عـن فقـرات هـذا المجـال تـم اسـتخدام المنوسـطات الحسابية والانحرافات المعيارية والدرجة للفقرات المنعلقة به. جدول(3) المتوسطات الحسابية والانحرافات المعيارية لفقرات مجال الانتباه مرتبة تنازلياً

\begin{tabular}{|c|c|c|c|c|c|}
\hline 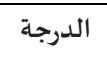 & 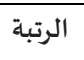 & الانحراف المعياري & المتوسط الحسابي & 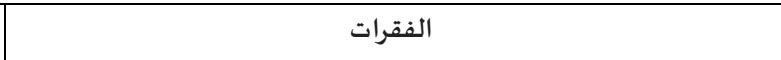 & رقم الفقرة \\
\hline مرتفعة & 1 & 0.77 & 3.98 & يوجه مدير المدرسة انتباهه إلى كل ما يدور حوله من مثيرات & 8 \\
\hline مرتفعة & 2 & 0.79 & 3.96 & يتمتع مدير المدرسة بحب استطلاع لتعرف كل ما هو جديد في مجال عمله & 1 \\
\hline 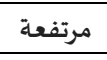 & 3 & 0.82 & 3.94 & يستفيد مدير المدرسة من آراء المعلمين & 3 \\
\hline مرتفعة & 4 & 0.85 & 3.87 & يستطيع مدير المدرسة تفهم مشاعر الآخرين في المواقف المختلفة & 5 \\
\hline 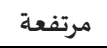 & 5 & 0.82 & 3.85 & يُغيّر مدير المدرسة موقفه عندما يقتنع بعدم صحته & 7 \\
\hline مرتفعة & 6 & 0.85 & 3.80 & يُقددر مدير المدرسة آراء المعلمين & 10 \\
\hline مرتفعة & 7 & 0.81 & 3.78 & يكون مدير المدرسة على وعي بكل الأفكار التي تدور من حوله & 4 \\
\hline مرتفعة - مرت & 8 & 0.84 & 3.72 & يرحب مدير المدرسة بالتحديات من قِبل المعلمين. & 9 \\
\hline مرتفعة & 9 & 0.88 & 3.70 & يتعامل المدير مع الأزمات بحيث لا تؤثر على سير عملية التدريس & 11 \\
\hline مرتفعة & 10 & 0.84 & 3.68 & يتقبل مدير المدرسة تقييم عمله سواء أكان صحيحاً أم خاطئاً & 6 \\
\hline متوسطة & 11 & 0.70 & 3.63 & لدى مدير المدرسة المقدرة على ابتكار الحلول المجردة للمشكلات التي تواجهه & 2 \\
\hline مرتفعة & & 0.67 & 3.81 & المجال ككل & \\
\hline
\end{tabular}

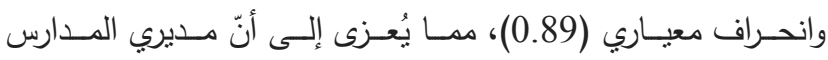
المجال الثاني: التمييز

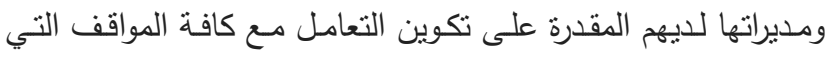
للإجابـة عـن فقـرات هـذا المجـال تـمّ اسـتخدام المتوسـطات الحسابية والانحرافات المعيارية والدرجة للفقرات المتعلقة به. تواجهر بكفاءة عالية، نظرا لامتلاكهم الخبرات السابقة التي تُكَّنهر من مواجهنها حيث يعمل على تشخيص الموقف ثم تقديم العلاج له عن طريق رسم خطط تعمل على علاج السلبيات وتعزيز الإيجابيات حسب استطاعته في رفع مسنتوى العملية التعليميـة داخل الدرسـة

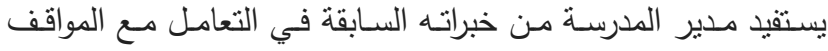

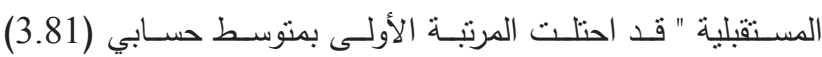


مـع أغلـب المواقف التـي تـواجهرم، فمـدير المدرسـة هـو المُحـرك الأساسي للعملية التعليمية التعلمية في المدرسة ، وهو نقطة الوصل في المدرسة الذي يعطي المدرسة كل أسباب التقدم ، وهو الذي يُحفز ويطور من الأداء على المستوى الجماعي والفردي فيخلق بيئة تعاون يون مثاليـة بـين المعلمين ويحـاول تطبيـق كل مـا يستجد على الصـعيد

$$
\text { التربوي. }
$$

وقد بلـغ المتوسط الحسـي لتقديرات أفراد العينـة على فقرات هذا المجال ككل (3.83) وانحراف معياري (0.59)، وهو بقابل تقدير

بدرجة مرتفعة،
وتحسين وتطوير أداء المعلمين وزيادة تحصيل الطلبة ، ويعملون على تشجيع روح التعاون والتشاركية في العمل ، والتعامل بفاعلية مع كافة العاملين، مما يؤدي الى الإبداع والتميز في البيئة التعليمية. بينما احتلت الفقرة (14) والتي نصت على لئي ليُمضي المدير وقتاً طويلاً للتفاعل مـع المواقف بفاعلية في أوقات الأزمات" على المرتبة الأخيرة بمتوسط حسابي (3.51) وانحراف معياري (0.90)، مما بُعزى إلـى أنّ بعض مـديري المـدارس ومـديراتها يخصصـون وقتـا قصـيرا للتعامـل مـع بعـض المواقـف التـي تـواجهرم، ويكـون بسـبب كثرة انشغالاتهم بالأمور الإدارية والتعليمية، وعدم توفر وقت كافٍ للتعامل

جدول(4) المتوسطات الحسابية والانحرافات المعيارية لفقرات مجال التمييز مرتبة تتازلياً

\begin{tabular}{|c|c|c|c|c|c|}
\hline 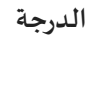 & الرتبة & المعياري المحراف & الحستوسط الحسب & 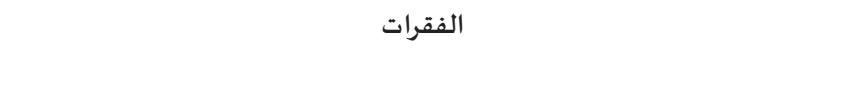 & رقم الفقرة \\
\hline 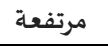 & 1 & 0.89 & 3.81 & يستفيد مدير المدرسة من خبراته السـابقة في التعامل مع المواقف المستقبلية & 15 \\
\hline 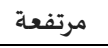 & 2 & 0.76 & 3.76 & يندمج مدير المدرسة بفاعليات العمل بكل سهولة ويسر & 13 \\
\hline 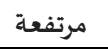 & 3 & 0.83 & 3.71 & يستطيع مدير المدرسة الإصغاء والعمل في نفس اللحظة & 12 \\
\hline 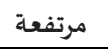 & 4 & 0.85 & 4.69 & لدى مدير المدرسة المقدرة على تمحيص الأفكار الجديدة لتطوير عمله بسهولة ويسر & 16 \\
\hline متوسطة & 5 & 0.87 & 3.52 & يُفاوض مدير المدرسة بشأن الاختلافات بين المعلمين دون تحطيم الآراء المتنوعة & 17 \\
\hline متوسطة & 6 & 0.90 & 3.51 & يُمضي المديروقتاً طويلاً للتفاعل مع المواقف بفاعلية في أوقات الأزمات & 14 \\
\hline 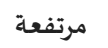 & & 0.59 & 3.83 & 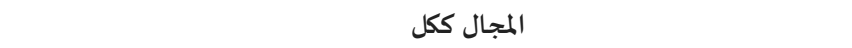 & \\
\hline
\end{tabular}

بينما احتلت الفقرة (21) والتي نصت على "مدير المدرسـة لا يُحيط علماً بما يجري في معظم الغرف الصفية" على المرتبة الأخيرة بمتوسط حسابي (3.26) وانحراف معياري (1.08)، مما يُعزى إلى أنّ

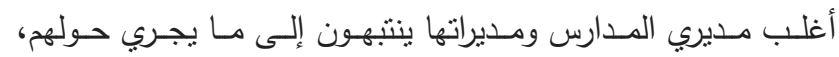
وخاصـة داخل الغرفة الصفية، من خلال الزيارات المفاجئة، ومتابعة المشكلات التي تواجه الطلبة داخل الغرفة الصفية بشكل مستمر ، مما يـوفر لليـه معلومـات كافيـة عمـا يـور في الغرف الصفية، وبالتالي مناقثتنها مـع المعلمين، لمسـاعدة المعلمين على تحديد مستوى أداء تعلـم الطـلاب، وتوظبـف المعرفــة المتعلقـة بـالتعلم والتـدريس ونمـو

$$
\text { الطلاب في القرارات التربوية . }
$$

وقد بلغ المتوسط الحسابي لتقديرات أفراد العينة على فقرات هذا المجـال ككل (3.78) وانحراف معيـاري (0.71)، وهـو يقابـل ثقدير

$$
\text { بدرجة مرتفعة }
$$

جدول (5) (5)
المجال الثالث: الملاحظة للإجابـة عـن فقـرات هـذا المجـال تـم اسـتخدام المتوسـطات الحسابية والانحرافات المعيارية والدرجة للفقرات المتعلقة به. يبين الجدول (5) أنّ الفقرة (23) والتي نصت على أنّه " يهتم مدير المدرسة بتقبل الأحداث المهمة في مجال عمله أكثر من التحكم فيها " قد احتلت المرتبـة الأولى بمتوسط حسـي (4.01) وانحراف

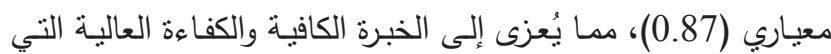
يمنلكها مديرو المدارس ومديراتها في التعامل مـع مجريات الأحداث التي تواجههم بكل هدوء وحنكـة، كمـا أنـاه يسـى نحو بنـاء خبـرات تعليمية منتوعة تتفق مع تتوع حاجات الطلاب والمعلمين واهتماماتهم،

\begin{tabular}{|c|c|c|c|c|c|}
\hline الدرجة & 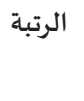 & المعياري & الحسبط المتوسط & 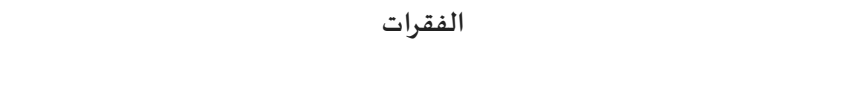 & 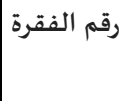 \\
\hline 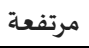 & 1 & 0.87 & 4.01 & يهتم مدير المدرسة بتقبل الأحداث المهمة في مجال عمله أكثر من التحكم فيها . & 23 \\
\hline 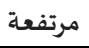 & 2 & 0.75 & 3.98 & يضبط مدير المدرسة مشاعره دون أن يدعها تقوده & 18 \\
\hline 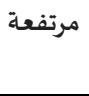 & 3 & 0.83 & 3.96 & يستمع مدير المدرسة الى وجهات النظر المختلفة من أجل إيجاد حل للمشكلات التي & 20 \\
\hline 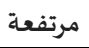 & 4 & 0.73 & 3.82 & يصف مدير المدرسة مشاعره ومعتقداته في كلمات منتقاة & 19 \\
\hline 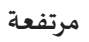 & 5 & 0.85 & 3.76 & ينتبه مدير المدرسة إلى كلّ ما يدور حوله من مثيرات & 22 \\
\hline
\end{tabular}
والسعي للتوصل إلى أفضل الحلول المناسبة.

المتوسطات الحسابية والانحرافات المعيارية لفقرات مجال الملاحظة مرتبة تتازلياً 
المجلة الدولية لضمان الجودة-المجلد الرابع -العدد الأول-2021

\begin{tabular}{|c|c|c|c|c|c|}
\hline متوسطة & 6 & 1.08 & 3.26 & مدير المدرسة لا يحيط علماً بما يجري في معظم الغرف الصفية & 21 \\
\hline 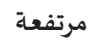 & & 0.71 & 3.78 & المجال ككل & \\
\hline
\end{tabular}

فرص أكثر للتعلم النـاجح، ومنابعـة الاتجاهـات الحديثة في الإدارة المجال الرابع: التفكير ودراستها وتطبيقها بشـكل مناسـب. بينمـا احتلت الفقرة (25) والتي

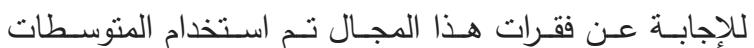
نصّت على "يصاب مدير المدرسة بشرود الذهن في أثتاء العمل" على الحسابية والانحرافات المعيارية والدرجة للفقرات المتعلقة به، والجدول المرتبـة الأخيرة بمتوسط حسـي (2.79) وانحراف معياري (1.17)، (6) يبين ذللك. مهـا يُعزى إلى أنّ بعض مديري المدارس يصـاب بشـيء من شرود الذهن بسبب ضغوط العمل التي تقع على عاتقه، فهو يتابع المعلمين والطلبة والإداريين ويسعى إلى الوصول إلى بيئة تعليمية متميزة.

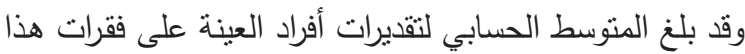
المجـال ككل (3.69) وانحـراف معيـاري (0.74)، وهـو يقابـل تقدير

بدرجة مرتفعة.

يبين الجدول (6) أنّ الفقرة (26) والتي نصّت على أنّه "يمنلك

مدير المدرسـة المقدرة للتتبؤ بالمشكلات المستقبلية في مجال العمل" قد احتلت المرتبـة الأولى بمتوسط حسابي (4.09) وانحراف معياري (0.81)، مما بُعزى إلى أنّ أغلب مديري المدارس ومديراتها بسعون إلى حلّ المشكلات قبل وقوعها، وبـثّ روح التعاون والمحبة بين كافة العـاملين للحصـول على بيئـة تعليميـة مميـزة، و تصــيم السياسـات المدرسية والإجراءات العملية مع الهيئة التعليمية والتربوية بهدف توفير

جدول(6) المتوسطات الحسابية والانحرافات المعيارية لفقرات مجال التفكير مرتبة تتازلياً

\begin{tabular}{|c|c|c|c|c|c|}
\hline الدرجة & الرتبة & المعياري & المستوسط & الفقرات & رقم الفقرة \\
\hline 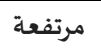 & 1 & 0.81 & 4.09 & يمتلك مدير المدرسة المقدرة للتنبؤ بالمشكلات المستقبلية في مجال العمل & 26 \\
\hline 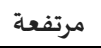 & 2 & 0.73 & 4.05 & يقوم مدير المدرسة بأكثر من عمل في نفس الوقت & 24 \\
\hline 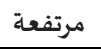 & 3 & 0.89 & 3.91 & لدى مدير المدرسة المقدرة على الدفاع عن أفكاره بالحجة والبرهان & 27 \\
\hline متوسطة & 4 & 0.92 & 3.63 & يستطيع مدير المدرسة الحكم على الأفكار المقترحة بأهها صالحة للتطبيق أم لا & 28 \\
\hline 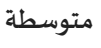 & 5 & 1.17 & 2.79 & يُصهاب مدير المدرسة بشرود الذهن في أثناء العمل & 25 \\
\hline 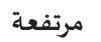 & & 0.74 & 3.69 & 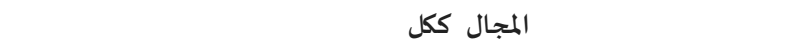 & \\
\hline
\end{tabular}

والتي نصّت على "يؤدي وظائفه بشكل آلي دون أن يُقدّر مـا يفعله" على المرتبـة الأخيـرة بمتوسـط حسـابي (3.39) وانحـراف معيـاري (1.01)، وتُعـزى إلـى أنّ أغلـب مـديري المـدارس مارسـوا العمليــة التعليمية داخل الفصول مما كوّن لايهم دراية شاملة بما يحدث داخلها وبالصـعوبات التـي يتعـرض لهـا الطلبـة والمعلمـون، والسـعي لحـلّ المشكلات، وتتمبة الإبداعات لايهم، والسعي إلى الوصول إلى التميز والإبداع وتقليل الفجوات بين الطلبة والمعلمين. وقد بلغ المتوسط الحسابي لتقديرات أفراد العينة على فقرات هذا المجـال ككل (3.71) وانحـراف معيـاري (0.66)، وهـو يقابـل تقدير

بدرجة مرتفعة،
المجال الخامس: الوعي للإجابـة عـن فقـرات هـذا المجـال تـم اسـتخدام المتوسـطات الحسابية والانحرافات المعيارية والدرجة للفقرات المتعلقة به. يبين الجدول (7) أنّ الفقرة (29) والتي نصّّت على أنّه " يجد مدير المدرسـة وجهات نظر مختلفة مـن أجل حلّ المشكلات التي تواجهه " قد احتلت المرتبة الأولى بمنوسط حسابي (3.87) وانحراف معياري (0.88)، وتُعزى إلى امتلاك أغلب مديري المدارس ومديراتها

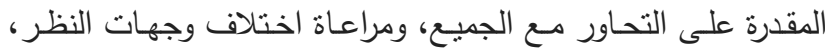
والسعي لإيجاد حلول ثُرضي جميع الأطراف، والتعامل مـع المعلمين والطلاب بقدر كبير من العلاقات الإنسانية. بينما احتلت الفقرة (33)

جدول(7) المتوسطات الحسابية والانحرافات المعيارية لفقرات مجال الوعي مرنبة تنازلياً

\begin{tabular}{|c|c|c|c|c|c|}
\hline 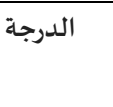 & 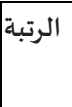 & المعياري & المتسابي & 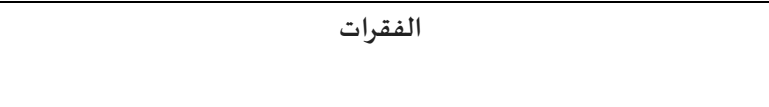 & رقم الفقرة \\
\hline 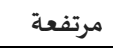 & 1 & 0.88 & 3.87 & يجد مدير المدرسة وجهات نظر مختلفة من أجل حلّ المشكلات التي تواجهه & 29 \\
\hline 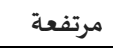 & 2 & 0.84 & 3.83 & يمتلك مدير المدرسة الوعي الكامل عندما يستقبل وجهات نظر الآخرين & 31 \\
\hline 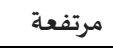 & 3 & 0.79 & 3.80 & يحرص مدير المدرسة على معرفة الرأي المخالف لرأيه للاستفادة منه & 30 \\
\hline 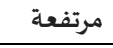 & 4 & 0.86 & 3.78 & يتشوق مدير المدرسة إلى معرفة الأشياء التي تثير انتباهه & 32 \\
\hline 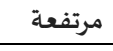 & 5 & 0.71 & 3.73 & يمتلك مدير المدرسة الخبرة في التدريس & 34 \\
\hline متوسطة & 6 & 1.01 & 3.39 & يؤدي وظائفه بشكل آلي دون أن يُقدّر ما يفعله & 33 \\
\hline مرتفعة & & 0.66 & 3.71 & المجال ككل & \\
\hline
\end{tabular}


وللإجابـة عن هذا السؤال تم استخراج المتوسطات الحسابية

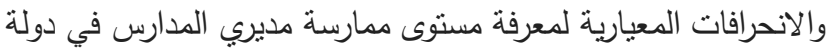
الكويت لاستراتيجيات إدارة الصراع من وجهة نظر المعلمين، والجدول

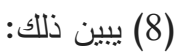

النتائج المتعلقة بالسؤال الثاني والذي ينصّ على: ما مستوى

ممارسة مديري المدارس في دولة الكويت لاستراتيجيات إدارة الصراع

من وجهة نظر المعلمين؟

جدول(8) المتوسطات الحسابية والانحرافات المعيارية لمعرفة مستوى ممارسة مديري الددارس في دولة الكويت لاستراتيجيات إدارة الصراع من وجهة نظر

المعلمين مرتبة تنتازيًا

\begin{tabular}{|c|c|c|c|c|c|}
\hline المستوى & 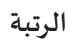 & الانحراف المعياري & المتوسط الحسابي & البعد البعد & 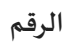 \\
\hline مرتفع & 1 & 0.72 & 3.93 & استراتيجية الإرضاء & 1 \\
\hline 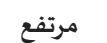 & 2 & 0.69 & 3.87 & استراتيجية التسوية & 2 \\
\hline مرتفع & 3 & 0.63 & 3.79 & استراتيجية التكامل & 3 \\
\hline 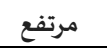 & 4 & 0.68 & 3.68 & استراتيجية التجنب & 4 \\
\hline متوسط & 5 & 0.62 & 3.37 & استراتيجية الهيمنة & 5 \\
\hline 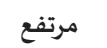 & & 0.66 & 3.72 & استراتيجيات إدارة الصراع ككل & \\
\hline
\end{tabular}

المدرسـة ومهارته في إدارة الصـراع بحيث يكون صـراعا إيجابيا من من فئن شأنه تحفيز العاملين وزبادة إنتاجيتهم وبذلك يكون الصراع موظفاً في الاتجاه الصحيح (البنّاء) وهذا يتحقق عندما يسود التكيف والرضا عن بيئة العمل الإنسانية وعن العلاقات السائدة بين الرؤساء والمرؤوسين،

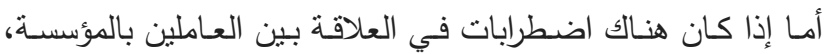
وفنِّل المديرُ في إدارة الصراع وتوظيفه بمعنى يكون سلبيا مما يقلل

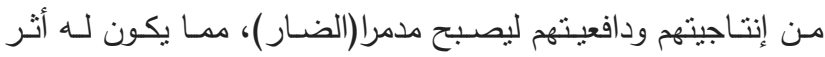
سلبي على القدرة الإنتاجية وكثرة الخلافات التي تؤدى إلى اللامبالاة والتكاسل في العمل مـع الثكوى والتمـارض، وعدم الالتزام بالتعليمات التي تصدر عن العمل ، وهذا كله يعتبر بمثابـة مِحَلكّ بـالغ الأهمية

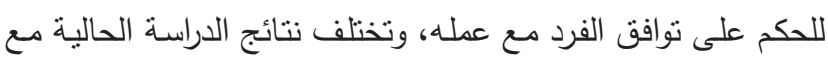
نتائج دراسة هنكين وآخرين (9)، ومع نتائج دراسة غنيم(8). وقد تم حسـاب المتوسـطات الحسـابية والانحرافـات المعياريـة لتقديرات أفراد عينة الدراسـة على فقرات كل مجال على حدة، حيث

$$
\text { كانت على النحو التالي: }
$$

\section{المجال الأول: استراتيجية التكامل}

للإججابـة عـن فقـرات هـذا المجـال تـم اسـتخدام المتوسـطات

الحسابية والانحرافات المعياربة والمستوى للفقرات المتعلقة به. يبين الجدول (9) أنّ الفقرة (4) والتي نصـت على أنّه "يعمل مدير المدرسـة على مشـاركة المعلمين في بحث قضـايا التعليم" قد احتلـت المرنبـة الأولىى بمتوسـط حسـابي (4.11) وانحـراف معيـاري

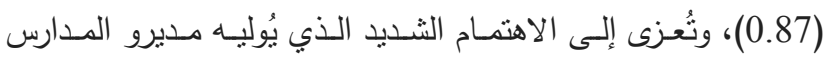

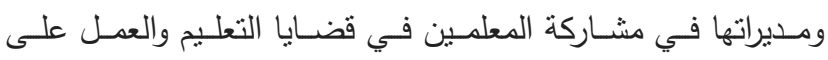
مناقتنها ومواكبة التطورات والتغييرات التي تطرأ، من أجل الحصول على بيئة تعليمية منميزة، كما بسعى أغلب مديري المدارس إلى تفهم

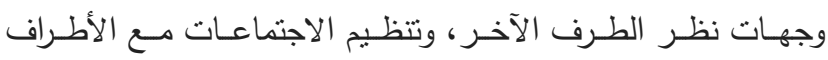

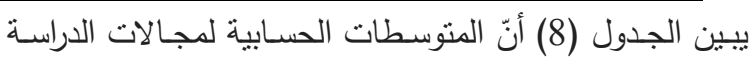
تراوحت ما بين (3.93- 3.37) حيث جاء مجال استراتيجية الإرضاء في المرتبـة الأولى بـأعلى متوسط حسـابي بلـن (3.93)، وبـانحراف معياري بلغ (0.72)، وبمستوى مرتفع، تناه في المرنبة الثانية مجال استراتيجية التسوية بمتوسط حسبي بلـغ (3.87)، وبـانحراف معياري

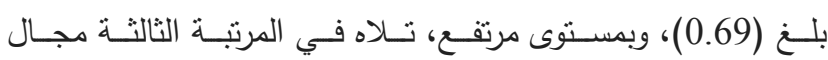
استراتيجية التكامل بمتوسط حسابي بلـغ (3.79)، وبانحراف معياري بلــغ (0.63)، وبمسـتوى مرتفـع، تــلاه فـي المرتبــة الرابعـة مجـال استراتيجية التجنب بمتوسط حسابي بلـغ (3.68)، وبـانحراف معياري بــنغ (0.68)، وبمسـتوى مرتفـع، وأخيـرا في المرتبـة الأخيـرة مجـال استراتيجية الهيمنة بمتوسط حسبابي بلـغ (3.37)، وبـانحراف معياري بلـغ (0.62)، وبمستوى متوسط، ممـا بُعزى إلىى أنّ مديري المـدارس

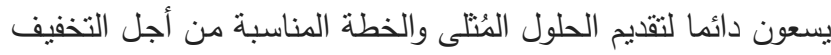
من حدة الخلافات والعمل على حلّها بأفضل الطرق وأنجعها، واتباع

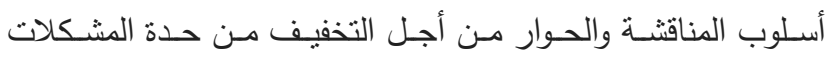
وتسـويتها، ويقـدمون لهـم المشـورة اللازمــة والاقتراحـات التحسـينية المناسبة مما يزيد من كفاءة المعلمين ويُحسّن بالتالي من جودة البيئة التعليميـة، ويحفز بينهم أسـلوب التعـاون والمشـاركة الذي يصسب في مصـلحة الطلبـة، و يتجنبـون الخـلاف مـع المعلمسين تجنبـاً للمشـاعر السـلبية، ويحساولون حـل الإشـالات بعيـدا عن الغضـب مسن خـلال الاستماع لهم وتقديم التوجيه المناسب مما يزيد من التعاون ويؤدي إلى توثيث أواصر المحبة والتعاون فيما بينهم، ويعزز لديهم روح المشاركة والمساعدة في العمل، والتعامل مع المعلمين بحزم من خـل استخدام

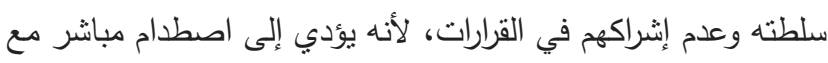
المعلمين ويزيد من الكراهية والبغضاء فيما بينهم مما بؤدي إلى التقليل مـن كفـاءة المعلمـين ويقلـل مـن جـودة البيئـة المدرسية، دور مـدير

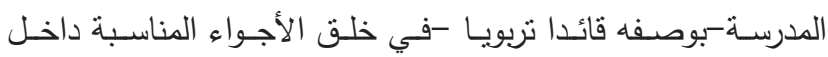


مستوى مرتفع. وتتفق مع نتائج دراسة هنكين وآخرين (9)، وتختلف مع دع نتائج دراسة غنبم (8).

المتصـارعة لبحث أسباب الصـراع، ومشـاركة العـاملين في وضـع الخطط والبرامج لمواجهة الصراع.

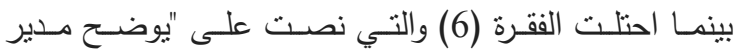
المدرسة اهتماماته بهدف حل القضايا بأفضل الطرق" على المرتبة الأخيرة بمنوسط حسابي (3.59) وانحراف معياري (0.90)، مما يُعزى باله

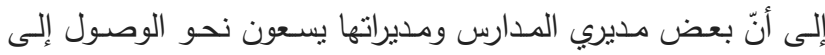
حلـول للمشكلات التي تواجههم بغض النظـر عن السـلبيات التي التي

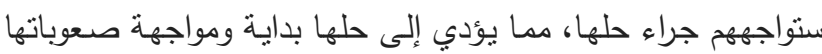

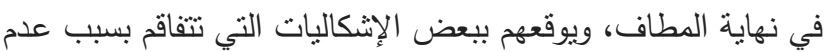
الاهتمام الكافي بحلّ بعض القضايا التي نواجهرم.

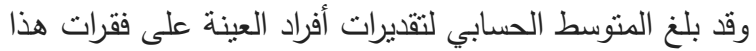
الدجال ككل (3.79) وانحراف معيـاري (0.65)، وهو يقابـل تقدير

جدول(9) الكتوسطات الحسابية والانحرافات المعيارية لفقرات مجال استراتيجية التكامل مرتبة تتازلياً

\begin{tabular}{|c|c|c|c|c|c|}
\hline 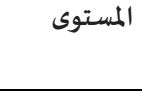 & 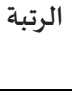 & المعياري & الحسسابي & 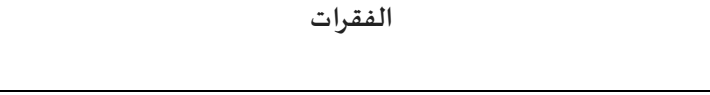 & رقم الفقرة \\
\hline 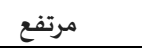 & 1 & 0.87 & 4.11 & يعمل مدير المدرسة على مشاركة المعلمين في بحث قضايا التعليم & 4 \\
\hline 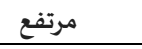 & 2 & 0.79 & 3.91 & يتعاون مدير المدرسة مع المعلمين للوصول إلى قرارات مناسبة للجميع & 1 \\
\hline 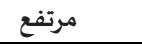 & 3 & 0.89 & 3.79 & ينّاقش مدير المدرسة القرارات الإدارية مع المعلمين & 3 \\
\hline 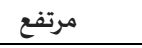 & 4 & 0.77 & 3.74 & يعمل مدير المددرسة مع معلميه للتوصل إلى فهم مشترك لمشكلة ما. & 2 \\
\hline متوسط & 5 & 0.80 & 3.61 & يتُّبادل مدير المدرسة المعلومات مع المعلمين & 5 \\
\hline 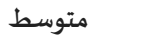 & 6 & 0.90 & 3.59 & يوضح مدير المدرسة اهتماماته بهدف حل القضايا بأفضل الطرق & 6 \\
\hline مرتفع & & 0.63 & 3.79 & المجال ككل & \\
\hline
\end{tabular}

المجال الثاني: استراتيجية التجنب

الفقرة (9) والتي نصت على "يتجاهل مدير المدرسة الصراعات على الفى الفي

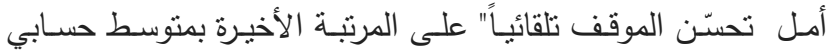
(3.46) وانحراف معياري (0.97)، مما يُعزى إلى أنّ بعض مديري

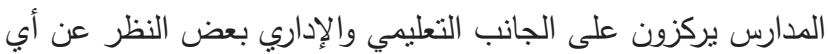
صراع بين المعلمين ما دام لا يؤثر على سير العطلية التعليمية. وقد

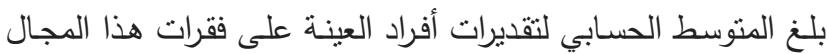
ككل (3.68) وانحراف معياري (0.87)، وهو يقابـل تقدير مستوى

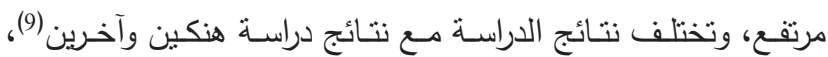
ودراسة غنيم (8)، ودراسة الجنابي(3).

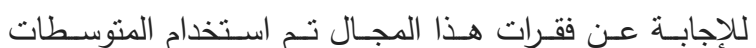
الحسابية والانحرافات المعيارية والمستوى للفقرات المتعلقة به. يبين الجـدول (10) أنّ الفقـرة (11) والتـي نصـت علـى أنّـهـ

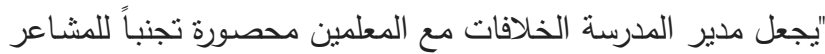
السلبية لهـم" قــ احتلـت المرتبـة الأولى بمتوسـط حسـابي (3.90) وانحراف معياري (0.79)، مما يُعزى إلى أنّ مديري الددرسة ومديراتها

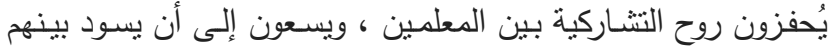

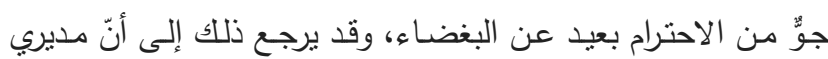

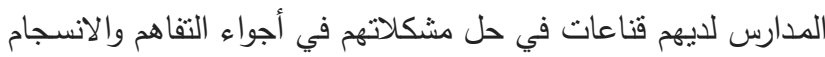

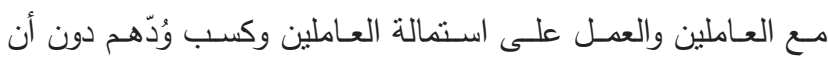
يضر ذللك بمصلحة العمل، بينما استخدام أساليب التجنب والمنافسة يخلق لديهم متاعب في إدارة المدرسـة. كذلك ظـروف العمل وتراكم الخبرة جعلت المديرين لديهم قدرة على الانسجام والتعاون مع الزملاء،

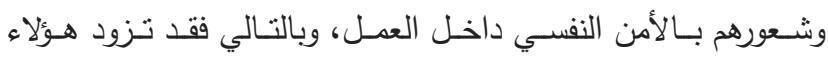
المديرون بحكم تجربتهم بأسـاليب وآليـات للتعاهل والتكيف دئ هـ هذه الظروف والأوضاع انطلاقا من إيمانهم بمصلحة العمل التي تتطلب

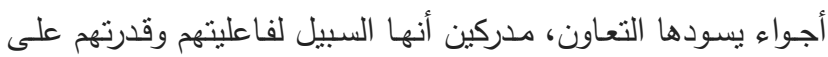

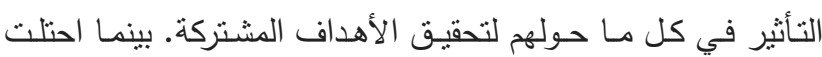


جدول(10) المنوسطات الحسابية والانحرافات المعيارية لفقرات مجال استراتيجية التجنب مرتبة تتازلياً

\begin{tabular}{|c|c|c|c|c|c|}
\hline 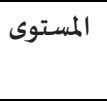 & 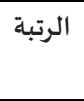 & |المعياري & المستوسط & 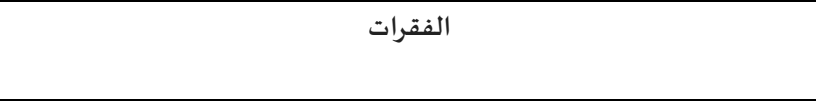 & رقم الفقرة \\
\hline مرتفع & 1 & 0.79 & 3.90 & يجعل مدير المدرسة الخلافات مع المعلمين محصهورة تجنباً للمشاعر السلبية لهم & 11 \\
\hline 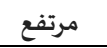 & 2 & 0.80 & 3.81 & يتبادل مدير المدرسة المعلومات مع المعلمين & 8 \\
\hline مرتفع & 3 & 0.79 & 3.76 & يتجنب مدير المدرسة أية مواجهة مع المعلمين & 7 \\
\hline متوسط & 4 & 0.88 & 3.63 & يبتعد مدير الممدرسة عن الخلافات مع المعلمين & 10 \\
\hline 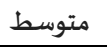 & 5 & 0.90 & 3.51 & يخفف مدير المدرسة حدة الصراع بين المعلمين بإهمالها & 12 \\
\hline متوسط & 6 & .97 & 3.46 & يتجاهل مدير المدرسة الصراعات على أمل تحسُّن الموقف تلقائياً & 9 \\
\hline مرتفع & & .68 & 3.68 & المجال ككل & \\
\hline
\end{tabular}

تشجيع روح التعاون والمشاركة بينهم. بينما احتلت الفقرة (16) والتي نصت على "يستخدم مدير المدرسة نفوذه للفوز في موقف فيه تنافس" روت على المرتبــة الأخيـرة بمتوسـط حسـابي (3.53) وانحـراف معيـاري (0.85)، مما يُعزى إلى أنه قليل من المديرين والمديرات يسعون نحو

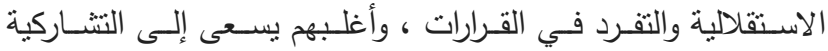
والتعاون مما يُثري البيئة التعليمية ويزيد الكفاءة والحماسـة بين جميع العاملين. وقد بلغ المتوسط الحسابي لتقديرات أفراد العينة على فقرات هذا المجال ككل (3.37) وانحراف معياري (0.62)، وهو يقابل تقدير مسـتوى متوسـط، وتختلـف نتـائج الدراسـة مـع نتـائج دراســة هنكـين وآخرين (9)، ودراسة غنيم (8)، ودراسة الجنابي (3).

المجال الثالث: استراتيجية الهيمنة

للإجابـة عـن فقـرات هـذا المجـال تـم اسـتخدام المتوسـطات

الحسابية والانحرافات المعيارية والمستوى للفقرات المتعلقة به. يبـين الجـدول (11) أنّ الفقـرة (14) والتـي نصــت على أنسه "يستخدم مدير المدرسـة الحزم بالدفاع عن وجهة نظره في القضـايا

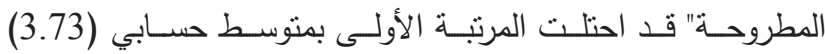
وانحراف معياري (0.77)، مما يُعزى إلىى أنّ مديري المدرسة ومديراتها يفكـرون في تسيير العمليـة التعليميـة حتى وإن كانـت هنـاك بعض الانتقادات، ممـا يجعلهم يتخذون قرارات ارتجالية لرؤيتهم أنها تصبّ في صالح استقرار العملية التعليمية في المدرسـة، والعمل على إكمال المسيرة التعليميـة ومحاولة إزالـة العوائق قدر الإمكان، والعمل على لـ

جدول(11) المتوسطات الحسابية والانحرافات المعيارية لفقرات مجال استراتيجية الهيمنة مرنبة تتازلياً

\begin{tabular}{|c|c|c|c|c|c|}
\hline 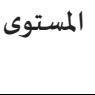 & 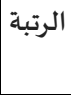 & المعياري & المستوسط & 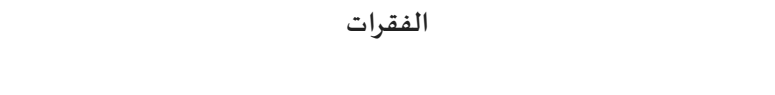 & 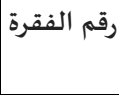 \\
\hline 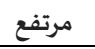 & 1 & 0.77 & 3.73 & يستخدم مدير المدرسة الحزم بالدفاع عن وجهة نظره في القضشايا المطروحة. & 14 \\
\hline 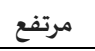 & 2 & 0.77 & 3.69 & يستخدم مدير المدرسة سلطته لاتخاذ قرار في مصلحته & 13 \\
\hline متوسط & 3 & 0.80 & 3.52 & يصهدر مدير المدرسة قراراته دون إشراك المعلمين في صنناعتها & 15 \\
\hline متوسط & 4 & 0.85 & 2.53 & يستخدم مدير المدرسة نفوذه للفوز في موقف فيه تنافس & 16 \\
\hline متوسط & & 0.62 & 3.37 & المجال ككل & \\
\hline
\end{tabular}

الإمكانيـات المُتاحـة، وتقريب وجهات النظر المتباينـة بين الأطراف

المتصارعة، وايجاد حلول توفيقية بين الأطراف المتصارعة. بينما احتلت الفقرة (21) والتي نصت على " بنـاقش القضـايا مـع المعلمين للوصـول إلى حلّ توافق بين الطرفين " على المرتبـة الأخيرة بمتوسط حسابي (3.71) وانحراف معياري (0.90)، مما يُعزى إلى أنّ أغلب المديرين والمديرات بيسون دومـا لفتح المجال لعرض وجهات النظر والعمـل على تقريبها، ممـا يؤدي إلى اسـتقرار البيئة التعليمية وفتح مجال الإبداع والتميز فيها. وقد بلغ المتوسط الحسابي لتقديرات أفراد العينة على فقرات هذا المجال ككل (3.87) وانحراف معياري (0.69)، وهـو يقابـل تقدير مسـتوى مرتفع، وتختلف نتائج

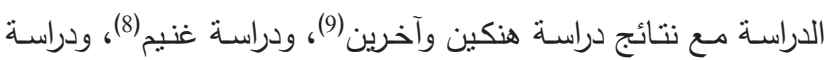

$$
\text { الجنابي) (3). }
$$

المجال الرابع: استراتيجية التسوية للإجابـة عـن فقـرات هـذا المجـال تـم اسـتخدام المتوسـطات الحسابية والانحرافات المعيارية والمستوى للفقرات المتعلقة به.

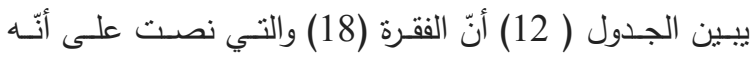
"يقترح مدير المدرسـة أرضية مشتركة لحسم الخلافات " قد احتلت المرتبـة الأولى بمتوسط حسـابي (3.98) وانحراف معيـاري (0.87)،

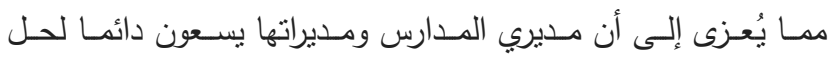

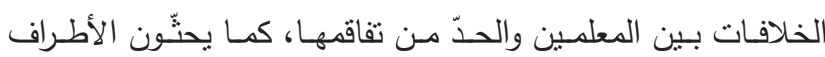
المتصـارعة على تقديم بعض التــازلات للتوصـل إلى تسـوية حول الصـراع، ومسـاعدة الأطراف المتصـارعة على تحقيق رغبتهـا حسب 
جدول(12) المتوسطات الحسابية والانحرافات المعبارية لفقرات مجال استراتيجية التسوية مرتبة نتازلياً

\begin{tabular}{|c|c|c|c|c|c|}
\hline 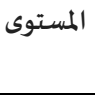 & الرتبة & المعياري & الحستوسط & 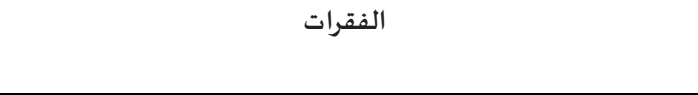 & 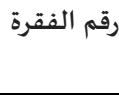 \\
\hline 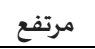 & 1 & 0.87 & 3.98 & يقترح مدير المدرسة أرضية مشتركة لحسم الخلافات & 18 \\
\hline 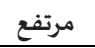 & 2 & 0.83 & 3.91 & يستخدم مدير المدرسة أسلوب الأخذ والعطاء للتوصل إلى حلّ وسط. & 17 \\
\hline 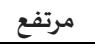 & 3 & 0.79 & 3.90 & يعمل مدير المدرسة على التوصل إلى حلّ وسط لمأزق ما. & 19 \\
\hline 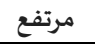 & 4 & 0.88 & 3.83 & يلجأ مدير المدرسة لتكوين علاقات طيبة مع المعلمين خارج المدرسة & 20 \\
\hline 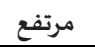 & 5 & 0.90 & 3.71 & يناقش القضايا مع المعلمين للوصول إلى حلّ توافق بين الطرفين & 21 \\
\hline 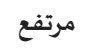 & & 0.69 & 3.87 & 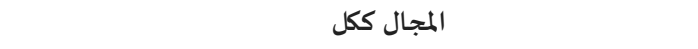 & \\
\hline
\end{tabular}

(3.87) وانحراف معياري (0.85)، مدا يُعزى إلى أنّ أغلب مديري الدارس ومديراتها يحاولون النظلي عن وجهات نظرهم من أجل إتمام العطلية التعليمية، وتجنب الدخول في نقاثـات واحتجاجات لها آثار

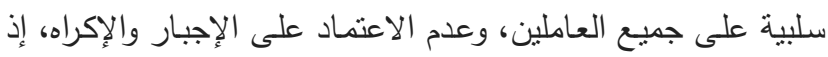

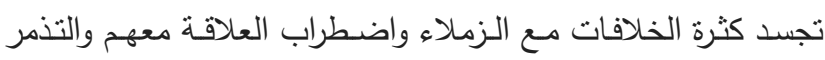
المستمر ، عدم الالتزام بالتعليمات وقلة الإنتاجية واللامبالاة والتكاسل

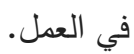
وقد بلغ المتوسط الحسابي لتقديرات أفراد العينة على فقرات هذا المجال ككل (3.93) وانحراف معيـاري (0.72)، يقابـل تقدير

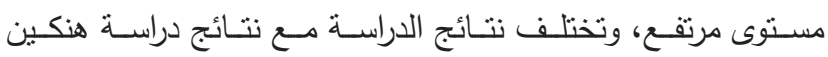
وآخرين (9)، ودراسة غنيم (8)، ودراسة الجنابي (3).

المجال الخامس: استراتيجية الإرضاء

للإجابـة عـن فقـرات هـذا المجـال تـم اسـتخدام المتوسـطات الحسابية والانحرافات المعيارية والدرجة للفقرات المتعلقة به.

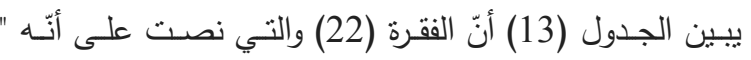
يحترم مدير المدرسة اقتراحات المعلمين لتعزيز مكانتهم " قد احتلت التحن المرتبـة الأولى بمتوسط حسابي (3.95) وانحراف معياري (0.77)، مما يُعزى إلى أنّ مديري المدارس ومديراتها يسعون إلى تلى تفعيل روح

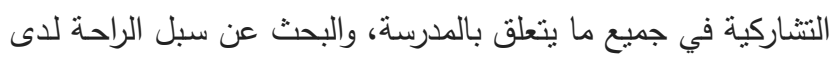

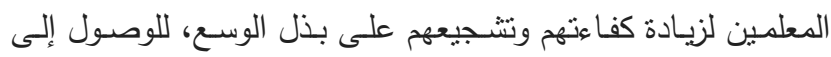

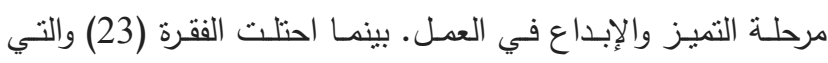

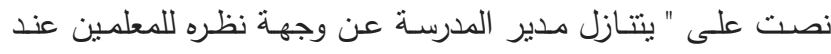

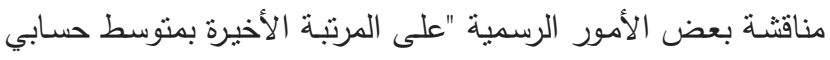

جدول(13) المتوسطات الحسابية والانحرافات المعيارية لفقرات مجال استراتيجية الإرضاء مرتبة تتازلياً

\begin{tabular}{|c|c|c|c|c|c|}
\hline 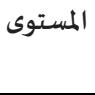 & 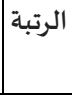 & المعياري & الحتوسط الحسبي & 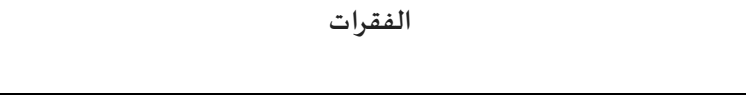 & رقم الفقرة | مق \\
\hline 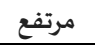 & 1 & 0.77 & 3.95 & يحترم مدير المدرسة اقتراحات المعلمين لتعزيز مكانتهم & 22 \\
\hline 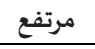 & 2 & 0.73 & 3.95 & يسعى مدير المدرسة إلى تلبية رغبات المعلمين ما أمكن & 24 \\
\hline 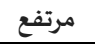 & 3 & 0.80 & 3.94 & يعمل مدير المدرسة على إرضاء حاجات المعلمين قدر الإمكان & 25 \\
\hline مرتفع & 4 & 0.85 & 3.87 & يتنازل مدير المدرسة عن وجهة نظره للمعلمين عند مناقشة بعض الأمور & 23 \\
\hline 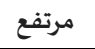 & & 0.72 & 3.93 & 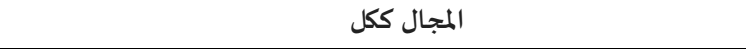 & \\
\hline
\end{tabular}

والتميز والنشاركية والاستفادة من الآراء، وضبط المشاعر تمكنهم من من المقدرة على التعامل مع استراتيجيات الصراع التنظيمي لدى المعلمين والمقدرة على التعامـل مـع جميع وجهات النظر المختلفة، ومحاولـة الوصسول إلى قرارات مناسبة ثُرضي أغلب العاملين، الحصـول على

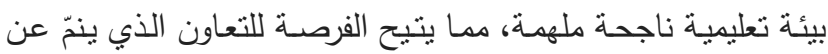

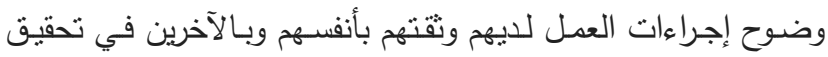
الأهداف المشتركة. كذلك العلاقات الاجتماعية الناجحة التي يقيمونها ورضاهم عن عملهم يُسهم في الشعور بالأمن والراحة داخل العمل مما يجعلهم يفكرون في الأعمال الجيدة، كما يمنحهم الحربـة في تقرير الطريقة التي يمارسون فيها عملهم. وبذلك تكون فرصـة حلّ الصراع

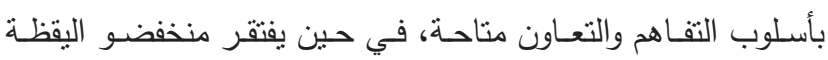
الذهنية إلى الانسجام مع الزملاء في العمل مدـا بخلق أجواء سلبية
النتائج المتعلقة بالسـؤال الثالث: هل هنـاك علاقة ارتباطية

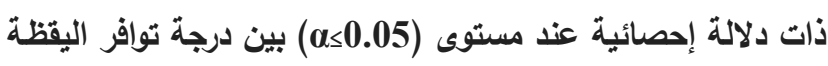
الذهنية لاى مديري المدارس في دولة الكويت ومستوى ممارستهم لاستراتيجيات إدارة الصراع؟ للإجابة عن هذا السؤال تم ايجاد مصفوفة معاملات الارتباط لبيرسون لدراسـة العلاقة بين درجـة توافر اليقظة الذهنية لدى مديري المـدارس في دولـة الكويـت ومسـتوى ممارسـتهم لاسـتراتيجيات إدارة

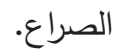
يُبـين الجـدول (14) أنّ هنـاك علاقــة ارتباطيـة إيجابيـة دالــة إحصائيا بين تقديرات أفراد العينة على درجة توافر اليقظة الذهنية لدى مديري المدارس في دولة الكويت ومستوى ممارستهم لاسـتراتيجيات إدارة الصـراع. ممـا بُعـزى إلىى أنّ امـتلاك مديري المـدارس ومديراتها درجـة عاليـة مـن الـوعي والانتبـاه لكل مـا يـدور حـولهم مـن مثيرات 
بين الرئيس والمرؤوسين فتغيب فرص التعاون والتفاهم والثقة وأجواء الارتياح في العمل.

جدول (14) مصفوفة معاملات الارتباط لبيرسون لكثف العلاقة بين درجة نوافر اليقظة الذهنية لدى مديري المدارس في دولة الكويت ومستوى ممارستهم

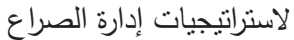

\begin{tabular}{|c|c|c|c|c|c|c|}
\hline \multicolumn{6}{|c|}{ مجالات استراتيجيات إدارة الصراع } & \multirow[b]{2}{*}{ مجالات اليقظة الذهنب } \\
\hline استراتيجيات إدارة الصراع & استراتيجيات الإرضاء| & استراتيجيات التسوية & |استراتيجيات | الهيمنة & استراتيجيات التجنب & استراتيجيات & \\
\hline${ }^{* *}-0.27$ & $*_{-0.19}$ & $* *-0.33$ & $*^{* *}-0.68$ & $*_{-0}^{*} 0.57$ & $*_{*}^{*} 050$ & الانتباه \\
\hline$*^{* *}-0.38$ & ${ }^{* *}-0.42$ & $*^{* *}-0.57$ & $*^{* *}-0.41$ & $*^{* *}-0.70$ & $*_{-0}^{*} 0.41$ & التمييز \\
\hline$*^{* *}-0.41$ & ${ }^{* *}-0.51$ & $*^{* *-0.33}$ & **-0.57 & ${ }^{* *-0.47}$ & ${ }^{* *}-0.47$ & الملاحظة \\
\hline **-0.72 & $*^{* *}-0.59$ & $*^{* *}-0.62$ & $*_{-*}^{*} 0.55$ & **-0.36 & **-0.35 & التفكير \\
\hline$*^{* *}-0.50$ & ${ }^{* *}-0.64$ & $*^{* *}-0.60$ & $*^{* *}-0.29$ & $*^{* *}-0.26$ & $*^{* *}-0.55$ & 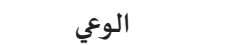 \\
\hline$*_{-}^{*} 0.61$ & $*_{*-0.67}^{*}$ & $* *-0.67$ & $*^{* *}-0.68$ & $*_{-0}^{*}-0.54$ & $* *-0.58$ & اليقظة الذهنية \\
\hline
\end{tabular}

).زّو دلالة احصائية عند مستوى الالالة (0.01).

organizational citizenship behavior for teachers from their point of view. Unpublished Master Thesis, Middle East University, Amman, Jordan,(2017).

3. Al-Janabi, Malik. The degree of practice of middle school principals in Baghdad governorate of organizational conflict management strategies and ways to develop them from their point of view, Unpublished Master Thesis, Amman Arab University, Jordan,(2017).

4. Alnamlatu, Suleiman bin Ibrahim. Management of Organizational Conflict in Secondary Schools in the Kingdom of Saudi Arabia, Unpublished Master Thesis, King Saud University, Saudi Arabia,(2007).

5. Al-Zubaidi, Marwa. Psychological stability and its relationship to mindfulness among middle school students, unpublished $\mathrm{PhD}$ thesis: Diyala University, Diyala, Iraq,(2012).

6. Awan, Saeed. Conflict Management and Organizational Performance: A Case Study of Askari Bank Ltd, Research Journal of Finance and Accounting, Volume 6, No. 11, (2015).

7. Gage, C. Q. The meaning and measure of school mindfulness exploratory analysis. DAI-A, 65(01),32, (2013).

8. Ghoneim, Ahmad, Strategies for managing conflict between teachers in government middle schools for boys in Madinah, Taibah University Journal, 1 (2), (2016).

9. Henkin, AB, Cistone, PJ, Dee, JR. Conflict management strategies of principals in site-based managed schools. Journal of Educational Administration 38(2): 142$158,(2000)$.

10. Marzouq, Ibtisam. Conflict Management Strategies followed by UNRWA Schools 
Principals in Gaza Governorates and Its Relation to Organizational Commitment of Teachers, Unpublished Master Thesis, Islamic University, Gaza, Palestine,(2011).

11. Masten, A.S.\& Reed, M.J.. Resilience in development. In Snyder, C.R.\& Lopez, S.J. (Eds), Handbook of positive psychology, New York: Wiley,(2002).

12. Najm, Hamza, and Sukkar, Ali. Strategies adopted in facing organizational conflict, a theoretical and practical study on a sample of school principals in Diwaniyah Governorate Center, Al-Ghari Journal of Economic and Administrative Sciences, 1 (30) 175-199, (2014).

13. Radhi, Ayman Abdel Qader. The Role of Decentralization in Effectiveness of Organizational Conflict Management in Ministries of Organizational Authority, Unpublished Master Thesis, Islamic University Gaza, Palestine,(2010).

14. Rahim, M Afzalur. A measure of style of handing interpersonal conflict. Academy of Management Journal,(2001).

15. Rodriquez. J.A. S. "Mindful instructional leadership: The connection between principal mindfulness and school practices" DAI-A 76(11) (E), (2016).

16. Tjosvold, D \& Ding, D. Conflict Management Training in China The Value of Cooperative Conflict Theory. Jnl of Teaching in Intl Business, 21 (2): 53 - 75, (2011). 